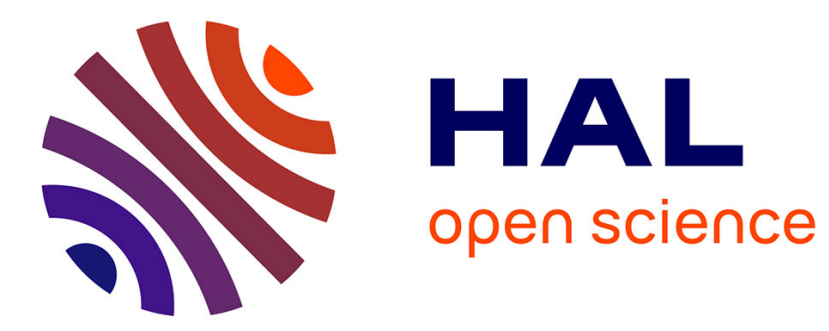

\title{
Inscriptions of Sumatra: Further Data on the Epigraphy of the Musi and Batang Hari Rivers Basins
}

\author{
Arlo Griffiths
}

\section{To cite this version:}

Arlo Griffiths. Inscriptions of Sumatra: Further Data on the Epigraphy of the Musi and Batang Hari Rivers Basins. Archipel, 2011, 81 (1), pp.139-175. 10.3406/arch.2011.4273 . halshs-01957930

\section{HAL Id: halshs-01957930 \\ https://shs.hal.science/halshs-01957930}

Submitted on 17 Dec 2018

HAL is a multi-disciplinary open access archive for the deposit and dissemination of scientific research documents, whether they are published or not. The documents may come from teaching and research institutions in France or abroad, or from public or private research centers.
L'archive ouverte pluridisciplinaire HAL, est destinée au dépôt et à la diffusion de documents scientifiques de niveau recherche, publiés ou non, émanant des établissements d'enseignement et de recherche français ou étrangers, des laboratoires publics ou privés. 


\section{Inscriptions of Sumatra: Further Data on the Epigraphy of the} Musi and Batang Hari Rivers Basins

Arlo Griffiths

\section{Citer ce document / Cite this document :}

Griffiths Arlo. Inscriptions of Sumatra: Further Data on the Epigraphy of the Musi and Batang Hari Rivers Basins. In: Archipel, volume 81, 2011. pp. 139-175;

doi : 10.3406/arch.2011.4273

http://www.persee.fr/doc/arch_0044-8613_2011_num_81_1_4273

Document généré le 14/04/2017 


\begin{abstract}
This is a review article of a catalogue of Sumatra inscriptions, recently published in Indonesia. After some remarks on this catalogue, the article presents details about twelve (groups of) inscriptions originating from the Musi and Batang Hari rivers basins, in the provinces of South Sumatra, Jambi and West Sumatra. Some items offer additional information (especially readings and translations) for entries in the catalogue, but most of them present inscriptions which were not included in the catalogue at all. Looking at new data from just three Sumatran provinces, it turns out that quite a lot of new epigraphic material still needs to be revealed to scholars. The new material throws light on the religious (especially Buddhist) history of the island, including its reflection in stone and bronze sculpture. It also comprises significant new data on the Old Malay language.
\end{abstract}

\title{
Résumé
}

Inscriptions de Sumatra : données complémentaires sur l'épigraphie des bassins de la Musi et de la Batang Hari

Cet article est le compte rendu d'un catalogue d'inscriptions de Sumatra, récemment publié en Indonésie. Après quelques remarques sur le catalogue en question, l'article présente les détails concernant douze (groupes d") inscriptions provenant des bassins des fleuves Musi et Batang Hari, dans les provinces de Sumatra-Sud, Jambi et Sumatra-Ouest. Certains de ces détails livrent des informations complémentaires (tout particulièrement en ce qui concerne les lectures et les traductions) à des entrées figurant au catalogue, mais la plupart des inscriptions présentées ici sont absentes de l'ouvrage concerné. Au regard de ces nouvelles informations relatives à seulement trois provinces de Sumatra, il s'avère qu'une quantité non négligeable de données épigraphiques inédites reste à faire connaître aux chercheurs. Ce nouveau matériel éclaire l'histoire religieuse de l'île (le bouddhisme en particulier), y compris à travers la sculpture en pierre et en bronze. II enrichit également notre connaissance du vieux-malais. 


\section{ÉTUDES}

\section{Inscriptions of Sumatra: Further Data on the Epigraphy of the Musi and Batang Hari Rivers Basins}

Compared to the wealth of epigraphical material using Indic systems of writing that has been preserved from Java, Bali or from other parts of Southeast Asia, the epigraphical record of the great island of Sumatra is very limited indeed. The different ecological conditions rarely favored here the type of rice-centered agricultural economies that formed the backdrop for recording the type of land-grants which constitute the bulk of Javanese (and Balinese as well as Khmer) epigraphy. Nevertheless, Sumatra too has yielded a number of inscriptions, which are of fundamental importance to such fields as the political and religious history of the region, and the history of the Malay language. The nature of the inscriptions varies with time and place, but at least one comparative generalization can be made, namely that economic transactions concerning the simma 'freehold', which form the

\footnotetext{
* This article is to a large extent based on the results of a memorable field expedition led by Pierre-Yves Manguin through Lampung, South Sumatra, Jambi and Bengkulu provinces in August 2010. I am deeply grateful to Manguin for sharing his great knowledge of Sumatran history and archaeology with me, and for providing me nearly all the building blocks to lay the foundations of my own first Sumatran investigations presented here. Two learned specialists of Nepalese and Eastern Indian epigraphy, Diwakar Acharya and Gourishwar Bhattacharya, have kindly shared their expertise on the materials written in Nāgarī script that are included in this article. Henri Chambert-Loir and Uri Tadmor have shared their critical remarks and expertise in Malay language, Cristina Scherrer-Schaub and Peter Skilling their buddhological knowledge. The various local officials and government institutions that have been of assistance in my research are mentioned below under the respective inscribed objects.
} 
dominant subject matter of the corpus of Javanese inscriptions on copper/bronze-plates, are in the present state of our knowledge entirely absent, ${ }^{1}$ as is the medium of the copper/bronze-plate itself.

Rightly observing that scholars interested in exploiting the data contained in the Sumatran inscriptions entirely lack materials to access them, ${ }^{2}$ the work Prasasti-Prasasti Sumatra (PPS) that forms the starting point of this article aims to fill this gap by providing a catalogue of known Sumatran inscriptions using Indic systems of writing. 3 The entries are organized in three great regions, comprising respectively the inscriptions of Southern, Central and Northern Sumatra. ${ }^{4}$ With a small number of exceptions, each one is provided with one or more black and white photographs of the inscribed object, sometimes including a close-up of the text directly from the stone or from a drawing or an estampage. The entries further comprise metadata such as provenance, present place of conservation, dimensions and material of the object; its archaeological context; date and language of the inscribed text; bibliographical references. Except in the case of very short inscriptions, the epigraphical texts are not cited either in original or in translation.

The catalogue does not define its understanding of the word prasasti, but it is clear that texts engraved on imperishable materials during the Islamic period (such as batu nisan, and the type of charters referred to as piagem that were issued by sultans in the lowlands) are excluded from its scope. In other words, prasasti means a text engraved on an imperishable material support using an Indic system of writing and showing no trace of the penetration of Islamic cultural or Arabic linguistic influence. Throughout this article, my use of the English word inscription is to be understood in the same sense.

The author admits at the outset that he is "incompetent with regard to script and language in reading inscriptions" (p.ix), and that he therefore needs to rely on "the research results of specialists of epigraphy". But the frequent reliance on unpublished and inaccessible works - not only those of the two highly revered deceased scholars (Boechari and S.K. Atmodjo) but

1. See below (p. 141) on the one or two (ostensible) exceptions to this generalization.

2. For the much more numerous Javanese inscriptions, we dispose of such tools since decades: e.g. Nakada's Inventory of the Dated Inscriptions of Java (1981), which offers quite comprehensive coverage of Javanese epigraphy (where undated inscriptions form a small minority).

3. This is a review article of: Bambang Budi Utomo, Prasasti-Prasasti Sumatra. Jakarta, Pusat Penelitian dan Pengembangan Arkeologi Nasional, 2007, ISSN 978-979-8041-433 . Not commercially marketed. All of the citations are my translations of the author's Indonesian.

4. References below use the abbreviations SBS/SBT/SBU for the sections on Sumatra Bagian Selatan/Tengah/Utara (Southern/Central/Northern Sumatra) in this work. 
also essays by university students - contributes to, rather than working towards a solution of the problem of the inaccessibility of data, as long as the sources in question remain available only to a very limited circle of scholars in Indonesia. The reliability of the data is another problem. It might have been better not to rely on the often immature work of university students in archaeology, as the author has done for the Hujung Langit inscription, both in his introduction (p. x) and under the entry for this inscription (p. 7), by asserting that it concerns the settlement of a sima, and suggesting that it contains the very word, apparently on the basis of information in a (nonaccessible) Universitas Indonesia skripsi dedicated to this unpublished inscription, which is difficult to read, but in which I have found no trace of the word sima. 5

There are a number of errors due to the author himself, of which we shall mention here only the following. The Bungkuk inscription (p. 9) is said not to have formed the subject of any special investigation, whereas in fact it formed the starting point of Boechari's important 1986 article "New Investigations of the Kedukan Bukit Inscription". This article is also missing among the references on p. 12 for the Kedukan Bukit inscription itself. The absence of fresh photographic documentation for a number of pieces ( $\mathrm{Si}$ Joreng Belangah, Hujung Langit) that are still in situ or still available in the National Museum at Jakarta makes it clear that the author has not attempted to see all the inscriptions for himself, with resulting small errors in indications about provenance: e.g., the mentioned Hujung Langit inscription falls within the kecamatan Sukau (not "Sukan") of regency Lampung Barat. Similar small errors are found throughout the work, and a few further examples will be mentioned in the footnotes below.

Notwithstanding such limitations, the work is a useful guide. The author himself realized that it was incomplete even when it went to the press (when two inscriptions had just been discovered in West Sumatra province, p. xii), 6 and indeed, during recent fieldwork visits in North Sumatra, West Sumatra, South Sumatra, Lampung and Jambi provinces, and through other channels, I have been able to collect quite a variety of data to correct and complete those recorded in this catalogue. Because I am presently preparing separate publications on the local corpus of Padang Lawas (North Sumatra) and on

5. I visited the site of the inscription in August 2010, and prepared two estampages. These do not yet allow me to publish the entire text (for which it will be necessary to return to the site, and ideally to prepare a better estampage), but do allow me to state with some confidence that the inscription does not contain the word sima.

6. I am aware of a notice of at least one of these recent finds, an inscription of Ādiyavarman: Rita Margaretha Setianingsih, "Prasasti Ganggo Hilia: temuan baru dari Sumatera Barat", in Berkala Arkeologi "Sangkhakala" (Balai Arkeologi Medan) 16 (2005): 63-78. 
the corpus of inscriptions associated with Ādityavarman (almost all from West Sumatra), and because in Lampung I have thus far only been able to visit the site of the Hujung Langit inscription, I would like to take the opportunity of this review article to present some finds from the provinces South Sumatra and Jambi along with one recent discovery from the Dharmasraya region of West Sumatra which, like Jambi, falls in the Batang Hari river basin. My intention here is to help correct or complete Bambang Budi Utomo's catalogue and to provide verifiable data in place of inaccessible or unreliable sources to which he refers. Items marked with an asterisk $(*)$ are not found in PPS and with one exception (my item *11) published here for the first time; the others were mentioned in PPS but I am able here to adduce significant new information, particularly with regard to the readings of the items in question.

\section{SOUTH SUMATRA}

\section{*1. ye dharmā inscriptions from Palembang}

One of the most common epigraphical traces of Indonesia's Buddhist past, from Sumatra to Bali, are objects (bronze statuettes, clay sealings, stūpikas, etc.) engraved or stamped with the Pratītyasamutpādagāthā, i.e. the ye dharma formula, often (misleadingly) referred to as the 'Buddhist creed'. There has never been much attention in Indonesian epigraphy for such objects, a problem that started in colonial times. W.F. Stutterheim, in the context of an important survey of Javanese art in European museum collections of 1924, already observed that "the importance of such inscriptions is greater than what the absence of historical particulars might give rise to expect. For the type of writing used can give us a clue for the dating of the [inscribed] images and so be of great value for stylistic history. Generally speaking, much too little attention has been given to these inscriptions ...". ${ }^{7}$ Stutterheim was still limiting himself to the cases where we find the ye dharma formula accompanying sculpture, but their interest is more general, all the more so if they are seen from a comparative perspective: ancient Indonesian Buddhism was a very cosmopolitan phenomenon, and its artifacts are eloquent testimony to this fact. In recent years, there have been a number of international publications in pan-Asian Buddhist studies on the topic of ye dharmā inscriptions (Boucher 1991; Skilling 1999, 2003-2004, 2005, 2008; Strauch 2009), and a classification scheme has been proposed,

7. "Het belang van zulke inscripties is grooter dan men, afgaande op het feit dat zij geen historische bijzonderheden vermelden, wel zou vermoeden. De gebruikte schriftsoort toch kan ons een leiddraad verschaffen voor de dateering der beeldjes en dus van groot nut zijn voor de stijlgeschiedenis. Over het algemeen genomen, heeft men veel te weinig nota genomen van deze inscripties [...]" (1924: 293f.). 
which it will be useful to think of applying for the dozens, if not hundreds, of Indonesian examples. I quote Strauch (2009: 49):

"Confronted with the extremely large number of objects inscribed with the so-called "Buddhist creed" or ye dharm $\bar{a}$ formula it is certainly recommendable to work out a systematic scheme for documenting this type of artefacts. Peter Skilling (1999) has proposed a text-oriented classification of inscriptions, dividing them according to their language affiliation (Pāli/Sanskrit) on the one hand, and according to their word order resp. lexical use on the other hand. This is an important first step, however, one might question whether this systematic approach should not be extended to other categories considering not only the internal textual evidence but also the context in which these texts occur. As a further step towards a workable systematics I would like to propose here a fivefold classification, which describes each object
A) according to the technology
B) according to the textual context
C) according to the pictorial context
D) according to its text
E) according to its find-spot.

These headings may be extended with regard to the actual object being described. Generally it would be advisable to involve also palaeographical data. But this can only be done at a later stage when a coherent terminology and dating method have been developed."

The first unpublished inscription to be presented here has curiously fallen through the nets of colonial period Dutch archaeologists, and its existence was pointed out to me by Pierre-Yves Manguin, who had become aware of it only by manually passing through the series of Oudheidkundige Dienst (OD) photographs of excavations undertaken in 1928 around the Bukit Seguntang in Palembang. 8 It was found there inserted into a brick, besides fragments of the large statue of the Buddha (now standing in front of the Museum Badaruddin in Palembang), ${ }^{9}$ but since the excavations were focused only on the recovery of sculptural remains was left unmentioned in Perquin's report that appeared in Oudheidkundig Verslag (OV) 1928. The list of photos from the excavation printed in OV 1929 apparently contains an error. Under item 9239, we read as description: "detail of the brick, in which the gold plate with inscription was found, cf. photo 1279 (9238)". 10 But the description of the preceding item, photo 9238 , does not mention a gold plate at all. In the

8. A database comprising all the more than 21.000 of these OD photos that arrived in public Dutch collections, before contacts between Indonesian and Dutch institutions finally became too severely weakened after decolonization, is searchable at https://socrates.leidenuniv.nl (under the collection "Kern Institute": use prefix "OD-" with hyphen for searches by OD number). A substantial number of photographs is already available in digital form.

9. A photo is included as fig. 5.1 in Brinkgreve \& Sulistianingsih (eds.) 2009: 72 .

10. "Detail $\mathrm{v} / \mathrm{d}$ baksteen, waarin het gouden plaatje met inscriptie werd gevonden, vergl. foto 1279 (9238)." 
series of prints of OD photos held in the collection of the Kern Institute at Leiden University, there is a photo of a metal plate under the number 9239, and this must be the gold plate in question (fig. 1a). From its archaeological context, Pierre-Yves Manguin (pers. comm.) leaves open two possibilities with regard to its dating: either from the building phase associated with the large Buddha statue $\left(7^{\text {th }}-8^{\text {th }}\right.$ century), or from the phase associated with $9^{\text {th }}-$ $10^{\text {th }}$ century ceramics. Palaeography here allows to narrow the choice down to the second phase. The text is so carelessly engraved that it would be impossible to decipher it, were it not for the possibility to read it inductively, based on the hypothesis that it contains the ye dharma formula. This hypothesis turns out to be verifiable, if we distribute the expected akșaras as follows, and mark those which are clearly legible in bold face (while placing those which are entirely illegible in parentheses):

(1) ye(dha)rmmā(hetupra)bhavohe

(2) tunteșāntathāgato

(3) hyavadatteșāñcayo ${ }^{11}$

(4) niro ... eva

(5) mvādīmahāâ(śrama)ṇa(ḥ)

While it remains unclear what the scribe was doing in line 4 , and in between that line and the preceding one (there is something interlinear below the $d a$ of line 3), the placement of the clearly discernible aksaras leaves no doubt that this is a case - however carelessly engraved - of the ye dharma formula, in the Sanskrit version found throughout the Indonesian archipelago, ${ }^{12}$ written neither in Siddhamātṛkā nor in a script resembling the 'late Pallava' script of the famous Śrivvijayan inscriptions of the late $7^{\text {th }}$ century (see item 2 below), but in 'Kawi' script resembling that of Javanese inscriptions of the $9^{\text {th }}-10^{\text {th }}$ century. In Strauch's refinement of Skilling's classification, this artifact would be described as follows:
A. $2 \mathrm{a} 2$ Gold plates
B. 1 Isolated
C. 1 Without any picture
D. 3a Sanskrit, hy avadat group
E. Inside a brick, likely part of a stūpa

Besides this unpublished ye dharmā inscription from Palembang, I may point out here the hundreds of clay "tablets" inscribed with the ye dharma

11. There seems to be an akșara below the da.

12. See for instance Chhabra 1965: 54-55 and Sukarto K. Atmodjo 1994: 1-2. For further references, see Cruijsen, Griffiths \& Klokke, forthc. 


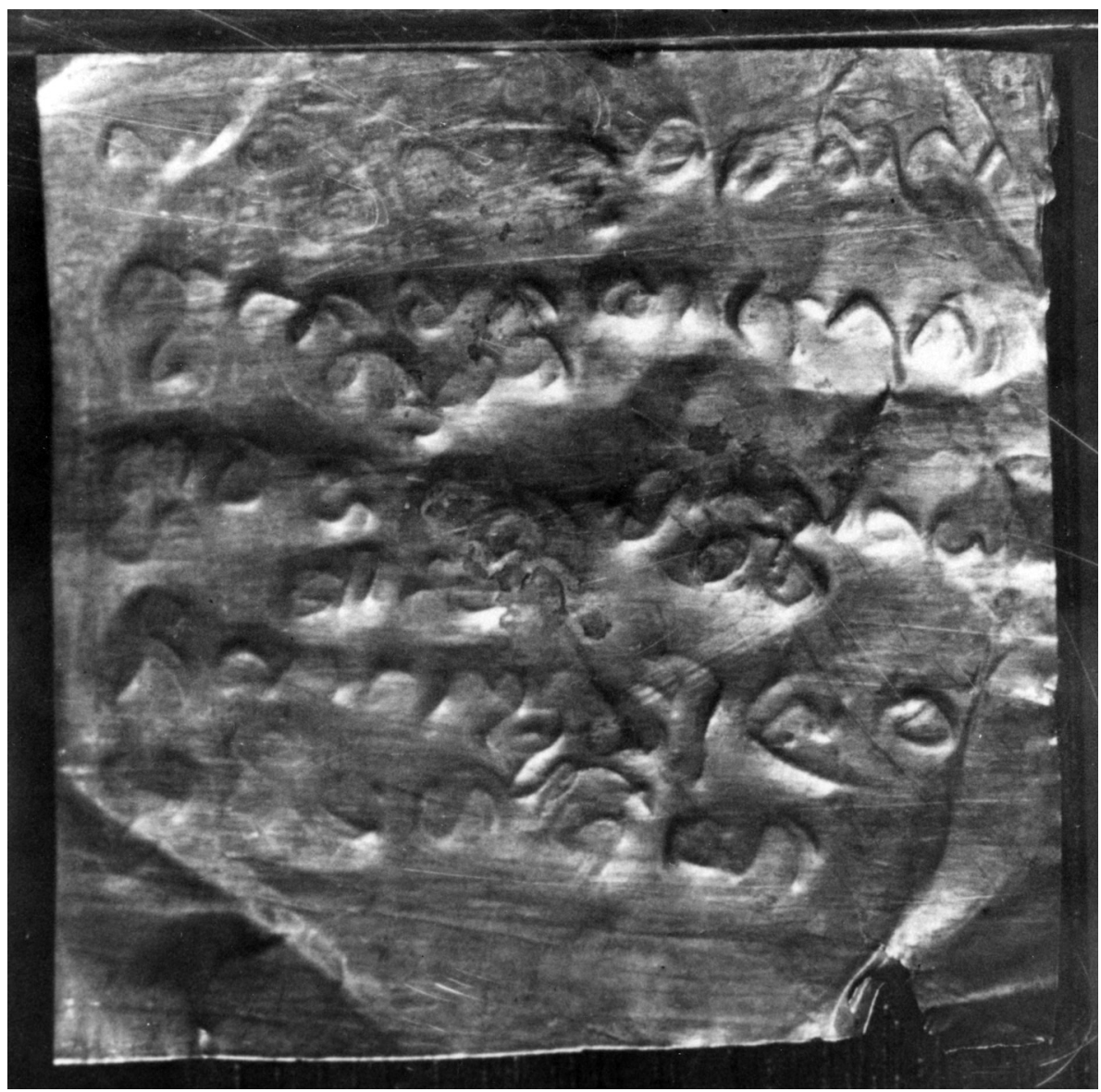

1a. A ye dharmā inscription from Bukit Seguntang, Palembang. (Photo OD 9239, taken in 1928)

formula, found inside stūpikas excavated at the Sarangwati site in 1974, on which there is a publication by Machi Suhadi (1976, with line drawings on: 59-61). 13 An earlier publication by Lamb had already featured photographs of two such tablets and two stüpikas, allegedly originating "from near Palembang" (1964: 59, with plates 43-46). Similar artifacts (apparently a seal and a sealing), which can hardly bear anything other than the ye dharma formula (although the text is illegible), were photographed by Pierre-Yves

13. A brief reference to these tablets was also included, with one line drawing (in Machi Suhadi 1989: 115 with eye-copy on p. 130). Both of Machi Suhadi's publications seem to have escaped Bambang Budi Utomo's attention. 
Manguin in 1987 (fig. 1b), when they were still in the hands of the looters who had taken them from a site north of Geding Suro, not far from the Sebokingking site, where the famous Śrīvijayan inscription formerly referred to as the inscription of Telaga Batu had been found (cf. Manguin 1987). There is thus evidence of Buddhist religious practices involving deposits of various types of objects inscribed with the ye dharma formula from several sites in Palembang.

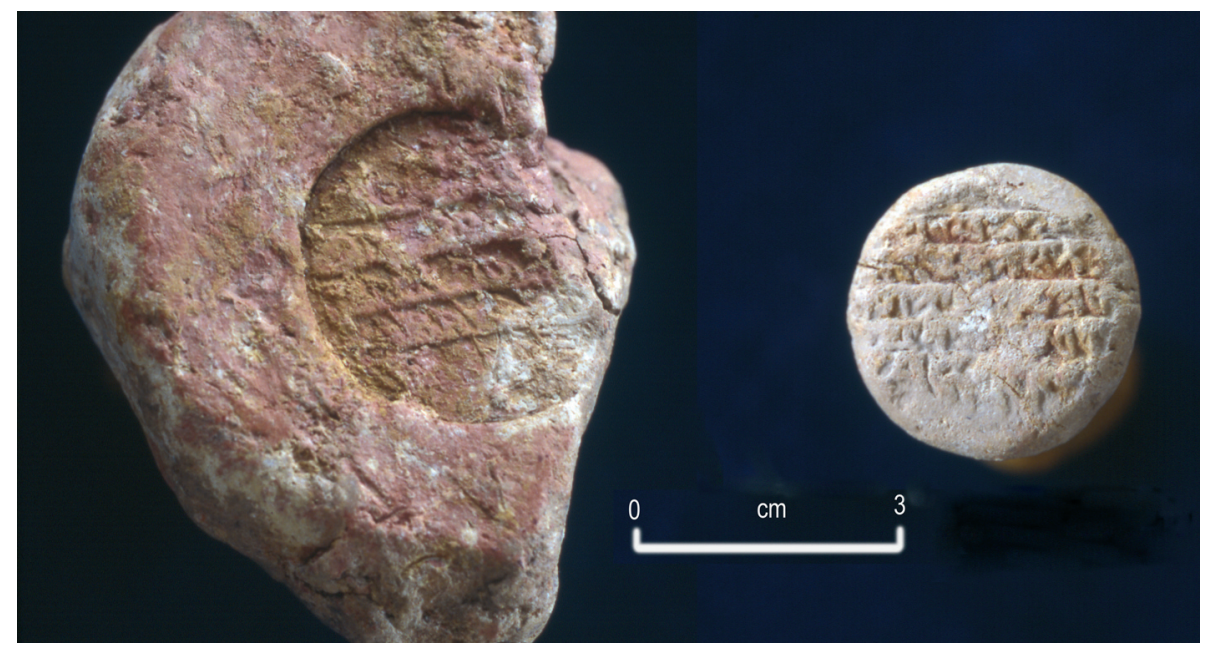

1b. Probable ye dharmā seal and sealing from Sebokingking, Palembang.

(Photo Pierre-Yves Manguin, 1987)

\section{Two unpublished fragments of a Śrīvijayan inscription}

In the Museum Balaputradewa and the Balai Arkeologi at Palembang, 14 are found one large and one small fragment containing text in Śrīvijayan Old Malay language. The type of stone is a soft sandstone that looks identical in both fragments. The dimensions of the large fragment are width $70 \mathrm{~cm}$, height $24 \mathrm{~cm}$, depth $18 \mathrm{~cm}$; 15 those of the small fragment are $24 \times 13 \times$ $17 \mathrm{~cm}$. Both were found at the site Kambang Purun in Palembang. 16 Judging from the agreement of language, script, material, provenance and one of the

14. I am most grateful for the kind help received at these two institutions from their respective directors Drs. Fahrurrozi D.MM. and Drs. Nurhadi Rangkuti M.Si, as well as from Dra. Sukanti at the Museum and Drs. Tri Marhaeni S.B. at Balai Arkeologi in August and December 2010. In neither institution have I found an inventory number for the frag ment held there.

15. The dimensions $60 \times 20 \times 15 \mathrm{~cm}$ cited in PPS are not precise.

16. According to PPS (SBS 18) the administrative divisions are kelurahan Bukit Lama, kecamatan Ilir Barat I, Kota Palembang. 
dimensions (depth), it appears quite likely that both fragments together belong to one original Śrīvijayan inscription in Old Malay, of whose upper end they would preserve two parts. The larger fragment is included in PPS (p. 23) under the name Kambang Purun, along with an illegible photo. A reading of Sukarto $\mathrm{K}$. Atmodjo is mentioned, but this appears to be unpublished and is not generally available. Despite the limited extent and disconnectedness of the fragments, the larger one comprises several complete phrases that permit syntactic analysis, and both yield important contributions to Old Malay lexicography. I was kindly allowed to make estampages of the two fragments in August and December 2010 (fig. 2a-b), and on this basis am able to publish here this small but interesting addition to the corpus of early Śrīvijayan epigraphy.

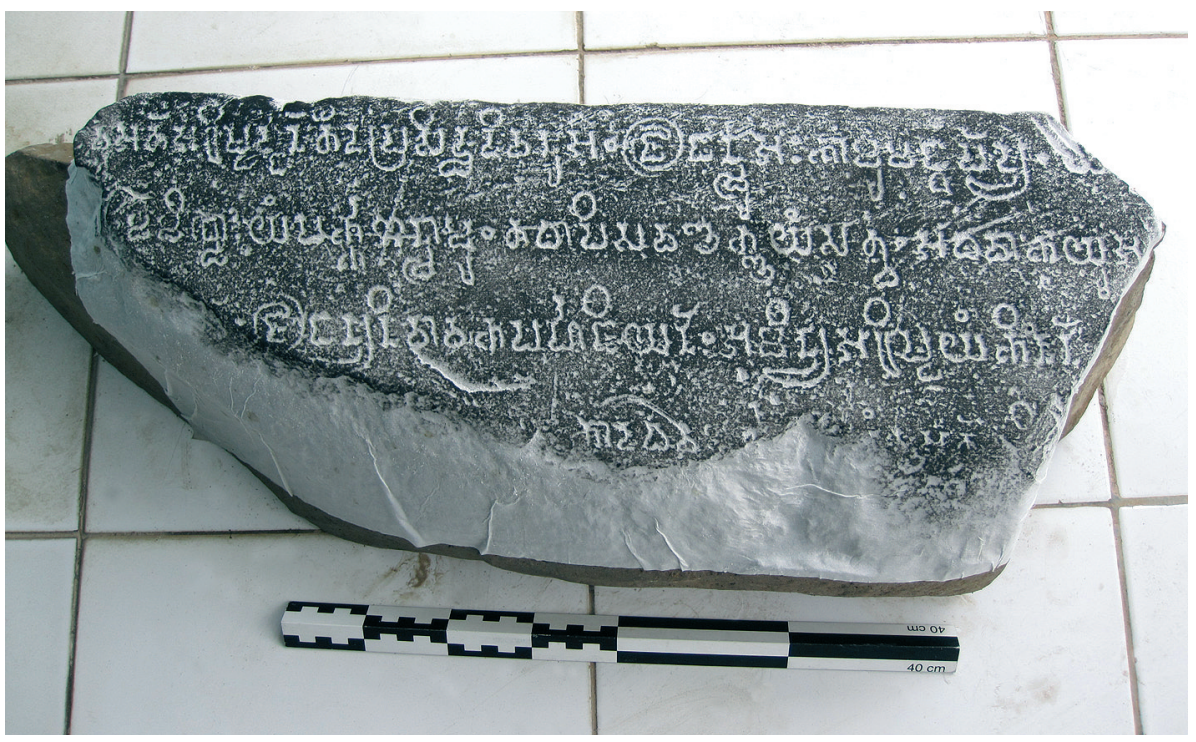

2a. EFEO estampage (manufactured in 2010) of the Kambang Purun inscription, large fragment.

\section{a. Large fragment (Museum Balaputradewa, Palembang)}

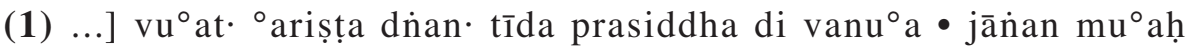
kāmumañgap 17 dya $\bullet$ (ya) $[\ldots$

17. The reading is absolutely certain here, and renewed study of the Bukit Seguntang inscription (PPS SBS 28) on the basis of the estampages I was able to make in August 2010 reveals that line 16, which was read as $\langle p r a>j a \overline{i n i}$ muara ya umamgap by de Casparis (1956: 5) actually reads jänan. $m u^{\circ} a h$ y $y a^{\circ}$ umamga(p). This demonstrates that the 
(2) ...] mamiṇụạ yaṃ parkka ${ }^{\circ}$ inmāmu • tathāpi savañakña yạ̣ satva • athavā kayu ${ }^{\circ}$ a $[\ldots$

(3) ...] jānan ya nivāva ka parhajiyan • • ${ }^{\circ}$ amin ya ${ }^{\circ}$ arișța yam kinan $[$ [...

(4) ...] kā $\left(\mathrm{da} /{ }^{\circ} \mathrm{u}\right)$ dhava $h\{3 / 4\} \mathrm{m}\{1\}^{\circ}$ at $C \mathrm{Ci}\left[\ldots{ }^{18}\right.$

This fragment luckily contains several complete sentences. It may be tentatively translated as follows:

'(1)... make unharmed without it becoming known in the city. You should not umangap him any longer. ... (2) move your sets of cloth (parkain). And/But all animals (satva), or the wood ... (3) that should not be brought to the palace (parhajiyan). All (amin) of them are unharmed who are righthanded (kinan) 19 ... (4) ...'

\section{*b. Small fragment (Balai Arkeologi, Palembang)}

(1) ...] (ma)rvvājik· markkiva [...

(2) ... ${ }^{\circ}$ itye]vamādi ${ }^{\circ} \mathrm{a}(\mathrm{ri})[\ldots$

On the second fragment, vamādi is directly recognizable as the end of the word ityevamādi frequently found in other Śrīvijayan inscriptions (e.g. below in item 3, line 6): it means 'etcetera'. For marvvajjik one thinks of the base bajik 'virtuous' in modern standard Malay; markkiva might be connected with kiwa 'left' (in some forms of Malay, and in Javanese), if the word boundary indeed corresponds with the right edge of the fragment. This fragment would seem to stand in the continuation of lines 1-2 of the larger fragment. On the assumption that the two indeed form part of one inscription, I propose to read on this fragment ${ }^{\circ} a(r i)$, the presumed $r i$ being a guess supported by the occurrences of ${ }^{\circ}$ arișta in the larger fragment.

\section{The Boom Baru inscription}

For this inscription, 20 which provides the most recently discovered instance of the Śrivijayan oath already known from the nearly identical versions recorded in the Kota Kapur, Karang Berahi, Bungkuk and Palas Pasemah inscriptions, reference is made only to Sukarto K. Atmodjo's 1992

verb is indeed umangap, as supposed by de Casparis (1956: 352), so that the sequence kämumañgap in the Kambang Purun inscription must stand for kāmu umangap. The same verb seems to be attested twice in the Old Malay 'Mañjuśrīgrnha' inscription found at Candi Sewu in Central Java, of which I am preparing a proper publication where I hope to be able to propose a translation suitable in all contexts. Such is not the case for the translations proposed by de Casparis on the sole basis of his erroneous reading of the context of the Bukit Seguntang attestation.

18. The capital $C$ indicates an illegible consonant, the italic $h$ uncertainty as to the presence of this sign. The numbers in $\{\ldots\}$ indicate an estimation of the number of lost akșaras. 


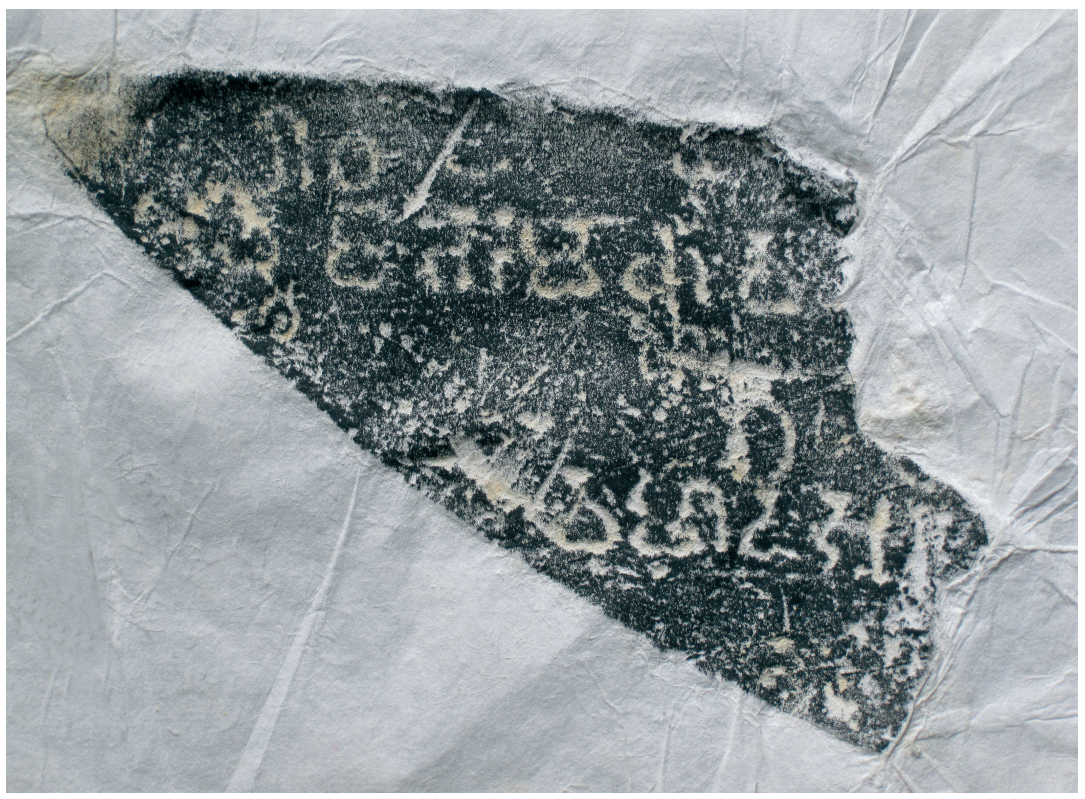

2b. EFEO estampage (manufactured in 2010) of the Kambang Purun inscription, small fragment.

publication. In fact, the same scholar has published the same inscription on no less than two other occasions (1993a: A2-2, 1994: 284f.), each containing basically the same reading but with quite a lot of misprints, especially with regard to diacritics (which are entirely omitted in the 1993a publication, the only one including a reproduction). I was kindly permitted to make estampages by the Museum Balaputradewa in August 2010 (fig. 3). Although we do not learn much new from this inscription, even less so since it is broken in two and some parts are entirely lost, it appears important to provide a reliable reading, using a standard of transliteration that allows for easy comparison with previously published Old Malay inscriptions and along with a reproduction that allows verification, as a basis for any possible

19. This translation for the final well-preserved words of the inscription is not more than a guess. I take the meaning 'all' for amin from Adelaar (1992: 203) who cites *amin as reconstructed Proto Malayo-Polynesian form, although it is assumed to have been entirely replaced by *habis already by the stage of Proto-Malayic. I take kinan in the meaning 'right-handed' from Stevens \& Schmidgall-Tellings, who indicate no particularity about this entry although I do not find it attested in other dictionaries available to me. I have no idea whether the guess proposed here has any chance of being on the mark.

20. Administrative divisions of the site of provenance ("kawasan pelabuhan Boom Baru"), according to PPS: kelurahan Lawang Kidul, kecamatan Ilir Timur I, Kota Palembang. 


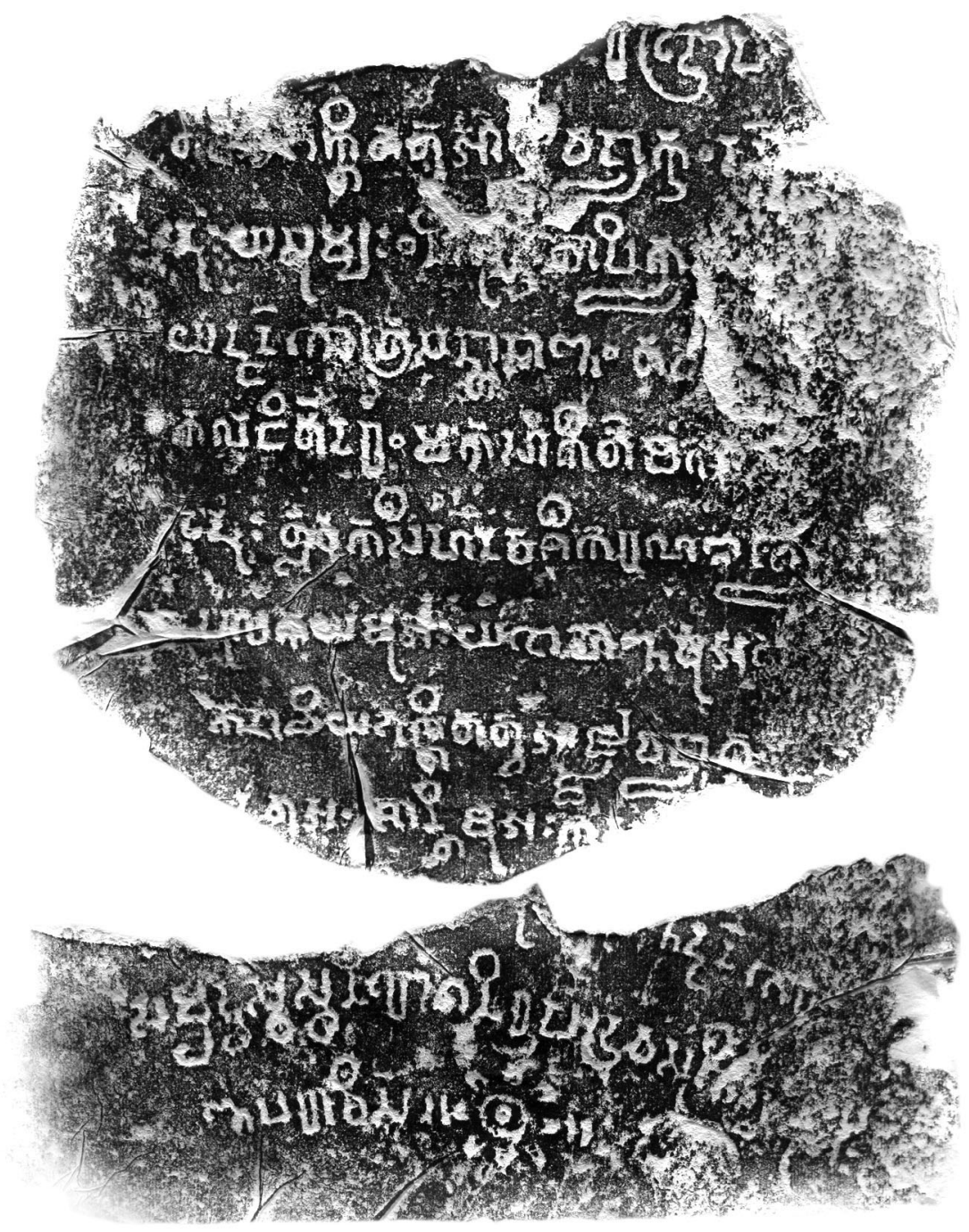

3. EFEO estampage (2010) of the Boom Baru inscription, in two parts. 
future comprehensive studies of the Srīvijayan corpus. Here follows my reading: 21

(1) ... ni $\left.{ }^{\circ} \mathrm{uj} \overline{\mathrm{a}}\right] \mathrm{r}[\mathrm{i}] \mathrm{dro}(\mathrm{ha})[\mathrm{ka} . .$.

(2) $\mathrm{t}(\overline{\mathrm{i}})\left[\right.$ da ya] bhakti tatva ${ }^{\circ} \overline{\mathrm{a}}(\mathrm{rjja}) \mathrm{va}$ dy $\overline{\mathrm{a}} \mathrm{ku} \bullet \mathrm{d}[\dot{\mathrm{n}}] \mathrm{a}(\mathrm{n}) \cdot[\ldots \mathrm{vu}-$

(3) nuh ya sumpaḥ • ni(s)uru(h) tāpik ya [...

(4) ya dn்an• gotrasantānāña • ta(th) [āpi ... ma-

(5) kalanit ${ }^{\circ}$ uraṃ • makasākīt• maka[gīla ...

(6) ${ }^{\circ}$ upuh tūva kasīhan vaśīkaraṇa ${ }^{\circ}$ itye[vamādi ...

(7) pulaṃ ka ya mu ${ }^{\circ}$ ạ̣ yaṃ doșāña vuª(t)[ña ...

(8) kadāci ya bhakti tatva ārjjava dy āku [...

(9) dat $(\overline{\mathrm{u}})^{\circ} \mathrm{a} \bullet$ sānti mu ${ }^{\circ} \mathrm{aḥ} \mathrm{ka(vu)}\left[{ }^{\circ}\right.$ atā] $(\tilde{n} a)$ dñan• go(tra)[santānāñā]

(10) samṛddha svastha nīroga nirupadrava subhikṣa mu ${ }^{\circ}$ ah (ya) [vanu $\left.{ }^{\circ} \bar{a}-\right]$

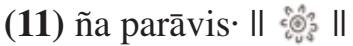

\section{*4. A bronze base for a triad of statuettes}

Another interesting new find is the small base for a triad of statuettes, all in bronze, allegedly dredged from the Musi river at Palembang, and currently held in a private collection (fig. $4 \mathrm{a}-\mathrm{e}$ ). The dimensions of the piece are $6 \times 16 \times 7,5 \mathrm{~cm}$. There is a small inscription engraved in one line on the front of the pedestal, formulated in Old Malay:

II padmaśri ya ${ }^{\circ} \mathrm{a}(\mathrm{m})$ puṇya 22 siliḥ vapuḥ ${ }^{\circ} \mathrm{a}(\mathrm{y}) \bar{a} n ̣(\mathrm{~d}) \mathrm{a}$ vapāṇda II

Assuming that an anusvära sign $(m)$ is really intended, I propose that $y a^{\circ} a m$ is a hitherto unattested spelling for the Old Malay relativizer /yay/ (spelt yam in all other epigraphical cases known to me), 23 and that punya here has its Malay sense 'to own' rather than one of its Sanskrit senses such as 'merit' or 'pious work'. 24 Further, I propose that silih vapuh (with vapuh, a Sanskrit word meaning 'form, body') corresponds in sense to Old Javanese

21. Since the text varies from other known versions only in minute details of spelling, omission of certain words or passages, and the fact that is has lacunae due to damage, there seems to be no need to provide a translation here. This will only be useful in the context of a comprehensive philological study.

22. There is an undulating sign above the $p u$ in punya. I cannot recognize it as a grapheme. If nevertheless it is one, it must be meant to note here a sequence like $m p u$, әтри or $\dot{n} и$. If not, it must be accidental or ornamental.

23. This being derived with the definite marker $m / \mathrm{h} /$ from the deictic pronoun $y a / \mathrm{ia} /$, the spelling seen here may hence be considered analytic in some sense, and the apparent hiatus was perhaps not intended, the separate $a k s \operatorname{sar}^{\circ} a$ rather being intended only to function as a support for the marker of definiteness but not to add a second syllable.

24. The latter would really, a priori, be more in line with the type of contents expected from such an inscription as this one, but I see no way to construe the sentence with punya 'merit, pious work' whether as noun or as verb. 

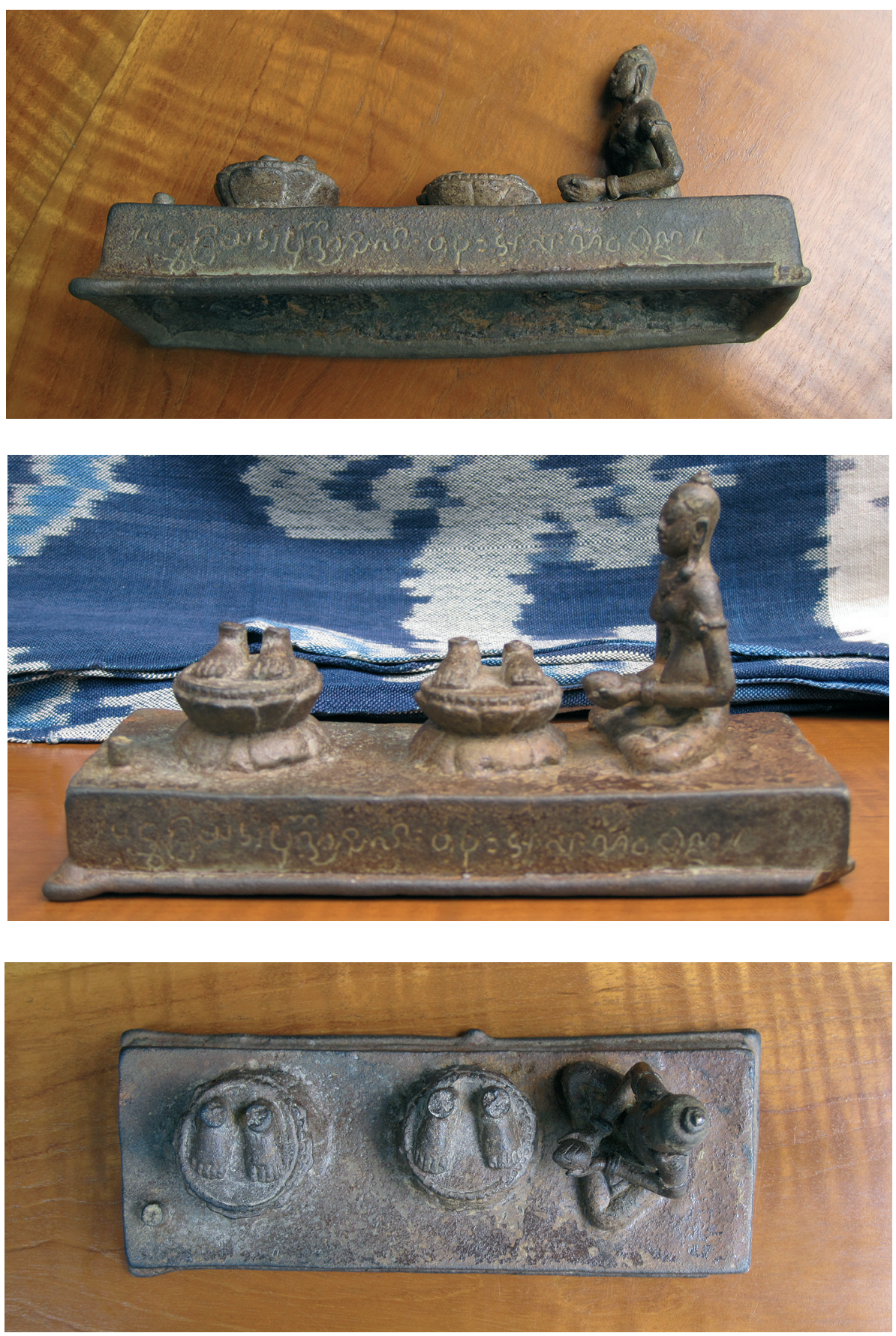

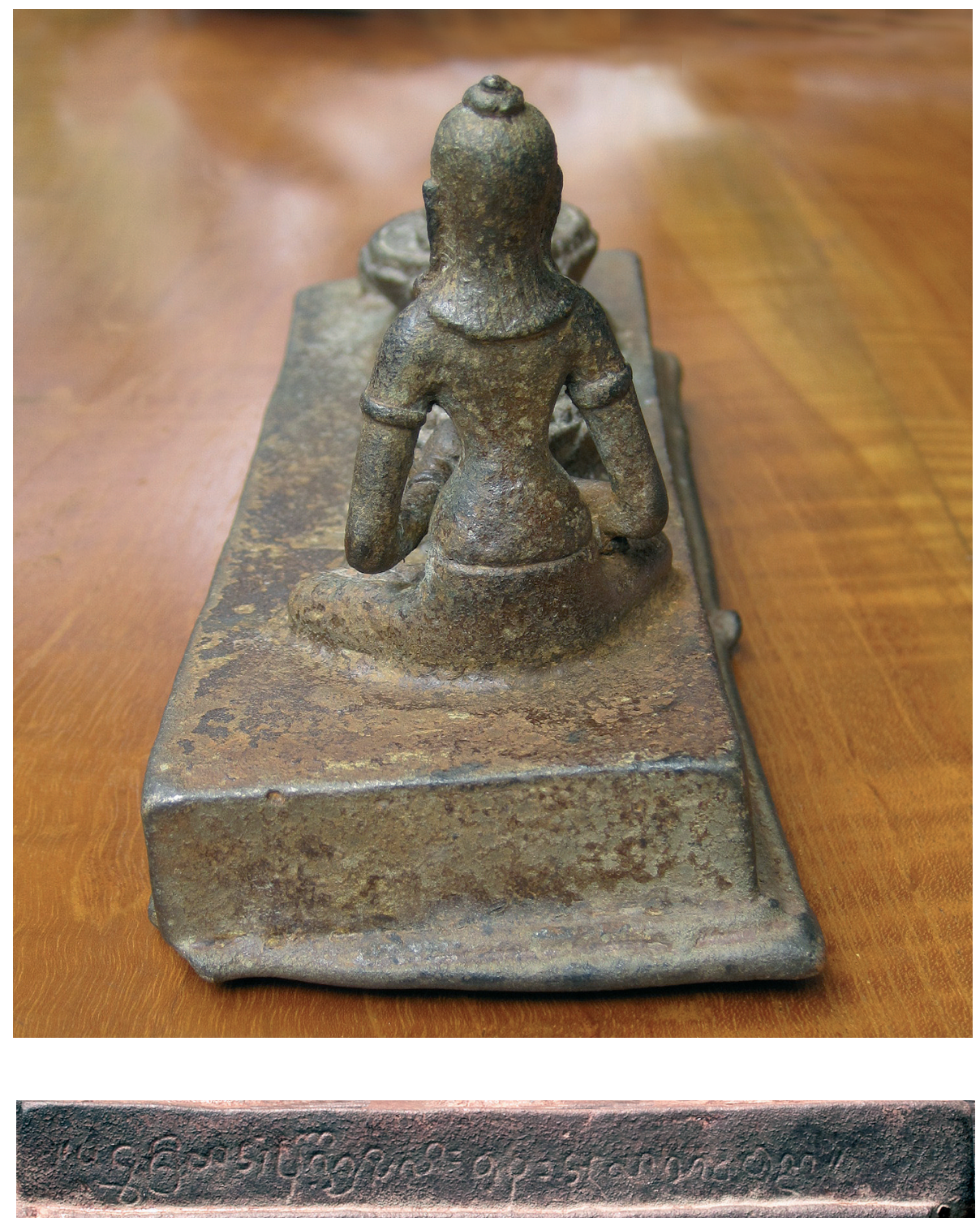

4a-e. A bronze base for a triad of statuettes. (Photos supplied by owner, 2010) 
silih diri 'substitute (for another person), esp. offering or victim'. The reading of the $5^{\text {th }}$ akșara from the end is problematic, but it can be understood as a carelessly written $y \bar{a}$. This allows us to read two kinship terms. ${ }^{25}$ Padmaśrī (to represent it in normalized form) is a Sanskrit name that might conceivably denote one of the three statuettes: Padmaśrī is one of the Buddhas of the ten directions, and is also one of the Buddhas of the present aeon (bhadrakalpa) in Buddhist cosmology. However, the name seems a bit more likely to denote here an ordinary human, in which case we have no certainty about the religious background (Hindu or Buddhist) of this object, and with regard to the gender of the owner. 26 The above considerations lead to the following two initial translation options:

'Padmaśrī. The owner (of this statuette) has replaced his/her mother [and] his/her father.'

or

'Padmaśrī is the owner replacing his/her mother [and] his/her father.'

However, it also seems perfectly imaginable that the element vapuh has a more pregnant meaning here, and that the expression silih vapuh denotes a 'physical representation, likeness, image', so we would be dealing with a case of portrait sculpture. In that case, we could translate:

'Padmaśrī is the owner of [this] likeness of his/her mother [and] his/her father.'

One might then speculate that the human devotee remaining on the right of the pedestal represents the owner. As for the two principal figures, the remaining pairs of feet are insufficient to propose any hypothesis as to the superhuman figures they might have presented (besides possibly representing the owner's parents). It is important to note that the left lotus cushion is slightly larger (h. 1,7; dia. 2,9 cm) than the one on the right (h. 1,4 $\mathrm{cm}$; dia. $2,7 \mathrm{~cm}$ ). For this and other reasons, it is safe to assume a larger (male) figure stood left, and a smaller (female) figure right.

No directly comparable pieces are known from Sumatra. There are some similarities between what remains of this sculpture and the much larger triad

25. The Old Malay Gandasuli II ('Sang Hyang Wintang') inscription from Central Java, published in Prasasti Indonesia I (nr. IV: 50-73; see Weatherbee 2000 for a significantly revised interpretation) contains a wealth of Old Malay kinship terms, including aya 'mother'. The present inscription however seems to yield the first Old Malay attestation of $v a p a / b a p a /$ 'father'.

26. No instance of this name is recorded in the indices to Tsukamoto 1996-1998 nor in Damais 1970. 
of Gunung Tua in Padang Lawas, northern Sumatra, for instance in the use of a stabilizing pole whose bottom we still see on the Palembang bronze, and which is intact but hidden behind the back of the central figure on the Gunung Tua bronze. The latter bears an inscription on the back of its base, which identifies the central figure as Bhațāra Lokanātha (i.e. Avalokiteśvara) and dates its manufacture to 1039 CE. 27 Damais (1955a: 376) considered the Gunung Tua inscription to use 'palaeosumatran' script, but did not specify which features led him to this classification. 28

Our inscription is cursive and therefore hard to compare palaeographically with the so-called 'late Pallava' writing of the late $7^{\text {th }}$ century Śrivijayan inscriptions, which would be the closest comparanda in geographical terms. Besides with the mentioned Gunung Tua sculpture of Northern Sumatra, the inscription invites comparison with the short Bukateja inscription, also written in Old Malay, but found in Java, which is roughly comparable in terms of content and form: 29 both inscriptions seem to provide an indication of the person who ordered the manufacture of the image on which they have been engraved; both lack internal dates and both are enclosed in pairs of vertical bars, by contrast with the dated Gunung Tua inscription which is more elaborate in its text and lacks the enclosing bars.

After careful palaeographic analysis, Damais (1968: 439) dated the Bukateja inscription around $800 \mathrm{CE}$. The script on our new piece strongly resembles Javanese writing of the Central Javanese period, but seems less archaic than that of Bukateja; on the other hand, it lacks any possible characteristic traits of Sumatran writing, such as have been implicitly attributed to the Gunung Tua inscription. Comparing the shapes of letters and some issues of spelling, I am inclined to situate our inscription somewhere between 800 and 1039, but somewhat closer to the latter, say somewhere in the $10^{\text {th }}$ century.

Parenthetically, it may be useful to state explicitly that I see no objection against comparing inscribed objects from Sumatra and Java. The period with which we are probably dealing is marked by a dearth of inscriptions in Sumatra, making it impossible to know whether any noticeable palaeographic differences had already occurred between the two islands at

27. Museum Nasional Indonesia 626d. See Brinkgreve \& Sulistianingsih (eds.) 2009: 62 (with reproduction as fig. 4.5 on p. 57); Damais 1955b: 207 for a reading of the principal Old Malay part of the text and its date. The MNI inv. nr. is misrepresented as $626 \mathrm{~b}$ in PPS, which also omits the bibliographic reference to Damais $1955 \mathrm{~b}$, and ignores the fact that this inscription also comprises a Sanskrit portion (SBU 04).

28. Trigangga's use of the synonymous term 'Old Sumatran' (2009: 86) only seems to take into account provenance but not any characteristic palaeographic features.

29. See my note on this inscription in Lunsingh Scheurleer (forthc.), where a photo will be provided. 
that time. Moreover many of the relevant inscribed objects, such as those under comparison here, are movable, which fact alone would make the application of any sharp distinction between Sumatran and Javanese writing for this period methodologically unsound.

\section{A gold plaque from Bumi Ayu}

A small gold plaque $(1 .: 8,5$; max. h. $0,8 \mathrm{~cm})$ recovered from the bank of the Lematang river at Bumi Ayu, 30 now held at Museum Balaputradewa under inv. nr. 04.28, is engraved with an inscription that figures as 'Om Yam' in PPS (p. 36). Reference is made there to a publication by Sukarto K. Atmodjo (1993b), which presents a reading on two sides (called recto and verso) and in three numbered parts. ${ }^{31}$ I was kindly allowed to inspect and photograph the plaque on 21 December 2010 (fig. 5a-c), and am now able to present my own reading, which is substantially different, although I agree with Sukarto K. Atmodjo that palaeography indicates a date in the $10^{\text {th }}-12^{\text {th }}$ century range. The plaque must be read from the left end up to the middle of the recto face (A), after which it must be flipped over like a lontar leaf to continue reading on the verso face $(\mathbf{B})$. I must admit that I was not able to retrieve at all Sukarto K. Atmodjo's part 3, which allegedly contained the words om yam after which the inscription has been named. The writing is exceptionally careless, so several readings proposed here are very uncertain (printed in italics), while those signs represented as $X$ are to me entirely unreadable.
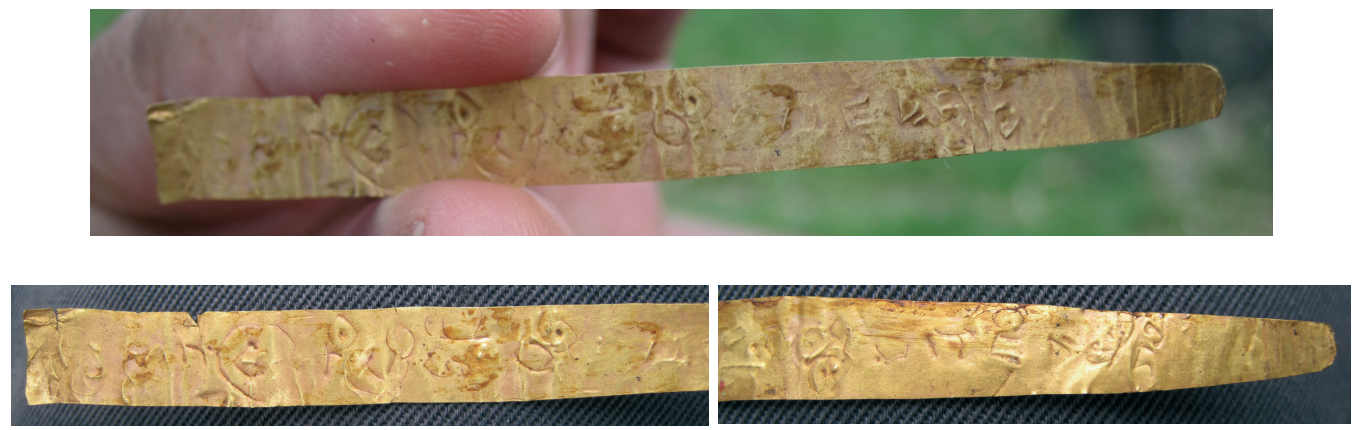

5a-c. Inscribed gold plaque from Bumi Ayu. (Photos Arlo Griffiths, 2010)

30. Administrative divisions according to PPS (SBS 31): desa Bumiayu, kecamatan Tanah Abang, kabupaten Muara Enim.

$\begin{array}{lll}\text { 31. Reading Sukarto K. Atmodjo: } & \text { Recto } & \text { Verso } \\ & \text { 1. bajra ri pritiwi } & \text { 2. pagani (paganu) carmani } \\ & & \text { (camani) } \\ & \text { 3. tan kuwu om myam }\end{array}$




\section{(A) $X X$ bhațārī prirtivī (B) ${ }^{\circ} e k a$ di $X$ mani}

It is certain that we have here the word bhatāa $\bar{l}$, misread as vajra ri by Sukarto K. Atmodjo. The name of this 'goddess' can hardly be anything other than prirtivi $\bar{\imath}(=$ prthiv $\bar{\imath})$ 'Earth', although the pri could be read as tri and the presumed rti is very awkwardly written. Too many uncertainties attach to the rest of the inscription for it to be useful to go into further details here. In any case, there is no mention of the Buddhist vajra, but this does not necessarily exclude that the religious ceremony in which this plaque played a role was Buddhist: the worship of 'goddess Earth' is not specific to any religion, while both Hinduism and Buddhism have left traces at Bumi Ayu. 32

\section{*6. Inscribed bricks from Bumi Ayu}

There are in the various Candis composing the Bumi Ayu complex dozens, if not hundreds, of bricks bearing writing. As far as I know, the only published reference to any such inscribed bricks is the cursory mention of "finds of fragments of brick inscriptions in Candi 1 which are written in Old Javanese letters and stem from the $10^{\text {th }}$ to the $11^{\text {th }}$ centuries" in a short article by Retno Purwanti, 33 which, notwithstanding the expectations raised by its title, yields no real information about these bricks. No mention is made of them in the catalogue PPS. A dedicated survey of the site would have to be undertaken to yield a list that might pretend to some form of comprehensiveness, so I must limit myself to the following two indisputable cases of writing:

- a brick preserved in the storage for loose terracotta objects near Candi II reads kisut., which according to the dictionaries would mean 'shriveled up', hard to make sense of in the context (fig. 6a).

- a number of bricks in the storage for objects from Candi III (apparently a stūpa) shows the akșara śri engraved sometimes neatly, sometimes quite carelessly. The same sign, sometimes so stylized as to suggest it had become a purely visual symbol, is founds in hundreds of cases on metal artifacts from Java (fig. 6b). 34

32. It may be useful to mention that another Indonesian gold plaque, originating from the northern part of central Java, bears the inscription batāri ratih (sic, with $b^{\circ}$ for $b h^{\circ}$ ), but here as label for the female image on the same plaque. This artifact is held in the Rijksmuseum voor Volkenkunde, Leiden, with inv. nr. 2196-1 (see Nandana Chutiwongs 1998: $218 \mathrm{f}$.). The inscription allows palaeographic dating to the 9 th-10th $\mathrm{c}$.

33. "temuan fragmen prasasti bata di Candi 1 yang ditulis dalam huruf Jawa Kuna dan berasal dari abad ke-10-11 M" (1994: 211).

34. Cf. Bosch 1927 on this motif. 

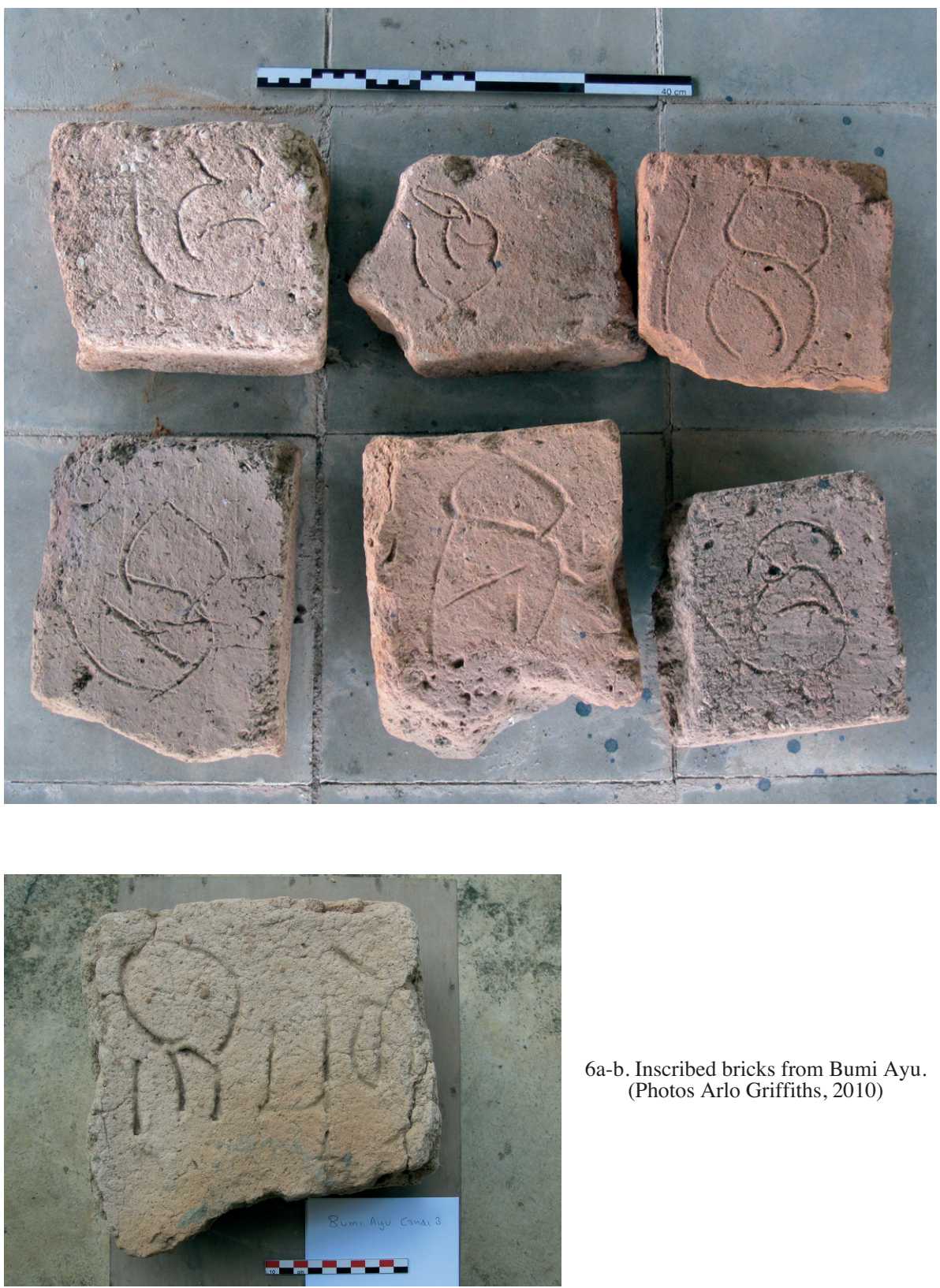

6a-b. Inscribed bricks from Bumi Ayu. (Photos Arlo Griffiths, 2010) 


\section{JAMBI}

\section{*7. A socle bearing an incomplete label (?) inscription}

The Museum Negeri Provinsi Jambi 35 holds a socle of what may have been a life-size statue with inv. nr. 04.04, recovered from the Solok Sipin site, which has also yielded the inscribed makara (now held in the Museum Nasional) which is item SBT 04 'Mpu Dharmmawîra' in PPS. 36 The case of this socle has perhaps been omitted in that catalogue because it is most unusual. The signs I propose to read as letters do not make a complete recognizable word, and anyhow must be read upside down in relation to the standing position of the socle on which they have been engraved, to yield the reading sam ${ }^{\circ} i$. This might have been the personal article sang and the first syllable of a name starting with $i$. The shape of the letters as well as the incoherent nature of what they express make this piece comparable to item SBT 01 'Koto Kandis' (also from Jambi province) in the catalogue. The estampage clearly shows that the signs must have been intentionally engraved, and can hardly be anything other than letters (fig. 7a-c).

\section{*8. A ye dharmā inscription from Muara Jambi}

This plaque presenting the ye dharma formula in curiously amputated form was found in the Perwara (subsidiary shrine) I of Candi Tinggi, in the Muara Jambi complex, which was already known to have yielded an important set of mantra inscriptions from the foundation deposit of Candi Gumpung. 37 It is now preserved at the Balai Pelestarian Peninggalan Purbakala (BPPP, Office for the conservation of antiquities) at Jambi, 38 where we were kindly permitted to photograph it in August 2010 (fig. 8). Its writing is a kind of eastern Indian Nāgarī, perhaps dateable to the $11^{\text {th }} \mathrm{c}$. CE, according to an estimate of Dr. Gouriswar Bhattacharya. The plaque is adorned with vajra-symbols at both extremities, in a manner that is reminiscent of two gold plaques from Biara Tandihat and Aek Sangkilon (Padang Lawas, Northern Sumatra) held at the National Museum in Jakarta

35. I am most grateful for the kind help received at this museum from its director Dra. Eka Feriani in August 2010, and the permission to make an estampage and photographs.

36. Administrative divisions according to PPS: desa Solok Sipin, kecamatan Jambi Kota, Kota Jambi.

37. PPS, SBT 03 'Mantram Buddhis'. Administrative divisions according to this catalogue: desa Muara Jambi, kecamatan Marosebo, kabupaten Muaro Jambi. Bambang Budi Utomo notes Boechari's Indonesian and English language reports on these finds, but the important contribution by Nihom (1998) has not come to his attention.

38. I am also most grateful for the kind help received at this institution from its director Drs. Winston SD Mambo and his staff member Agus Widiatmoko SS, MM in August 2010 and during the months thereafter. 

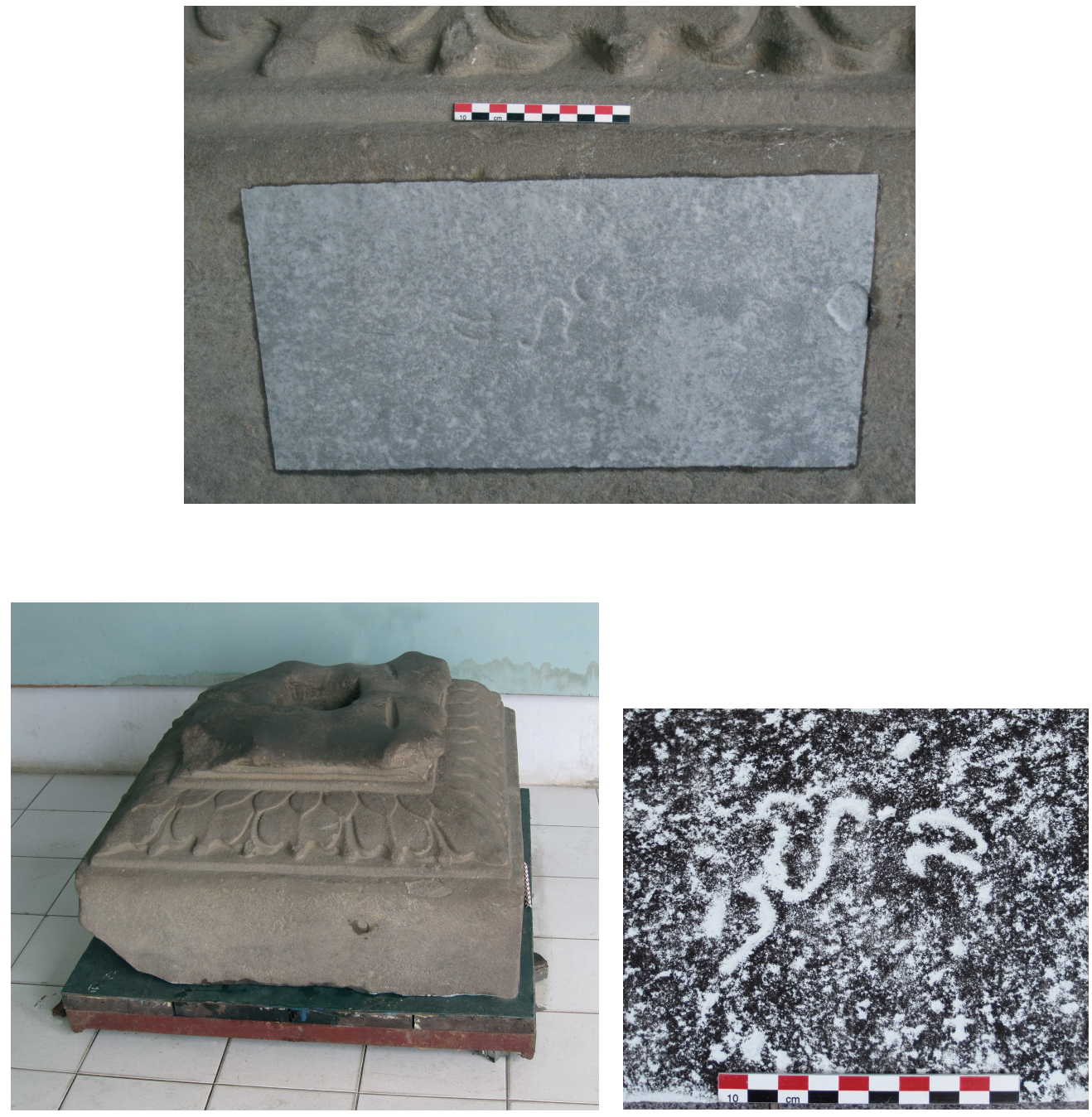

7a-c. Inscribed socle from Solok Sipin and EFEO estampage. (Photos Arlo Griffths, 2010) 
(inv. nrs. 6146 and 6149), 39 which both show a viśvavajra at their center. In contradistinction to those two plaques from Padang Lawas, and the following plaque from Muara Jambi, the present plaque does not show punctured rims, but a folded upper and lower long rim.

(1) je dharmmā hetuprabhavā hetu svāhāḥ II

(2) (hya)vadatteyava[ṃ]vādī I māhāśravaṇa I40

This version of the ye dharma formula, with insertion of the mantrifying element $s v \bar{a} h \bar{a} h$ (for $s v \bar{a} h \bar{a}$ ), is extraordinarily corrupt. Indeed, with one exception (namely the following item), I do not know any other version of the formula recovered from the Archipelago that presents it in more garbled and amputated state. The fact that the opening word is spelt je (for ye) possibly reveals the influence of an Eastern Indian (Bengali, Oriya) pronunciation on the part of scribe. According to the classification discussed above, it must be described as follows:
A. $2 \mathrm{a} 2$ Gold plates
B. 1 Isolated
C. 1 With a Buddhist symbol (the inscribed surface shows vajra- extremities)
D. 3a Sanskrit, hy avadat group, but very corrupt
E. In a subsidiary shrine of a monument

We find an even further transmogrified fragment of the formula in the following item.

\section{*9. A mantra inscription from Candi Tinggi (Muara Jambi)}

This simple gold plaque was found in the East gateway of Candi Tinggi, in the same complex. It is now preserved at the BPPP at Jambi, where we were kindly permitted to photograph it in August 2010 (fig. 9). 41

to hy avadat $\mathrm{t}(\mathrm{e})$ - șā(m) ca jravacī $m \bar{a} m \bar{a}{ }^{42}$

39. A rather vague photo of the latter has been published as fig. 6.8 by Brinkgreve \& Sulistianingsih (eds.) 2009: 93.

40. Diwakar Acharya has been of particular assistance for the proper reading of this plaque.

41. This is probably the "gold leaf ... $12 \mathrm{~cm}$ long and $4 \mathrm{~cm}$ wide" mentioned but not read by Machi Suhadi (1985: 261).

42. The hyphen indicates a place for one akșara. It is not clear if indeed there is one, or if the space has been left open. The italics indicate aksaras whose reading is uncertain, and which do not seem to make any sense in any way. Their reading was proposed to me by Diwakar Acharya. I was myself inclined to read cak ravacī. 
The first half of this inscription is clearly taken from the ye dharma formula, but since it represents less than a quarter of that formula, and the remainder of the inscription clearly does not belong to any known version of the formula, I am at a loss to decide whether this should be classified as a ye dharma inscription or not.

\section{*10. A mantra inscription from Candi Gedong I (Muara Jambi)}

This unusual case of a plaque comprising two parts of very different color (and presumably metallurgic composition) was found on 24 October 1998, in bricklayer 4 of Candi Gedong I, north face, in the same complex. It is now preserved at the BPPP at Jambi, where we were kindly permitted to photograph it in August 2010 (fig. 10). It consists of a half that appears to be in gold (A) and a half that appears to be in silver (B), 43 each bearing one line of writing giving a very different palaeographic impression. The natural suggestion of a very different date may however be misleading, because the difference in the shape of the letters may be explainable due to the difference of writing techniques: the letters have been punched into the gold half, and scratched into the silver half. The form of superscript $i$ (i.e. the sign called hulu in Java) is the same on both halves, and the text is continuous. We recognize up to and including ma(häpra)tiśare (for mahapratisare) the fifth mantra that is found in some manuscripts of the Mahapratisar $\bar{a}$ mahāvidyārājiñ , a Sanskrit text comprising the scriptural corpus connected with the worship of the Buddhist goddess of protection Mahāpratisarā. This mantra is emblematic of the Mahāpratisarā-tradition and is found in various other Buddhist texts, although it is also found in some Hindu Sanskrit texts (see Hidas 2007: 189-190, n. 21; 2010: 481, n. 72; and Cruijsen, Griffiths \& Klokke, forthc.).

(A) // ${ }^{\circ}$ oṃ maṇidhāri bajr(i)ṇi mahā(pra)(B)tiśare tamyāásāáatamvadhiṃ pari 'Om. O Amulet-holder! O the One with a Vajra! O Mahāpratisarā/Great Amulet! ...'

We might expect to find here a personalized variant of the mantra om maṇidhari vajriṇi mahāpratisare dhārakasya rakṣām śāntipuștịn kuru hūṃ hūm phat phat svāhā 'Oṃ O Amulet-holder, O the One with a Vajra, O Great Amulet, provide protection, peace and prosperity for the holder hūm hüm

43. It is perhaps useful to point out that the technique of combining two halves respectively manufactured of gold and of silver into one piece is not completely unique, but is seen also in the repoussé gold-silver Harihari (National Museum in Jakarta, inv. nr. A76/6068) shown as item 66 in the catalogue Treasures of Ancient Indonesian Kingdoms (Tokyo National Museum 1997: 113). One may presume that the use of this combination had some symbolic significance. 


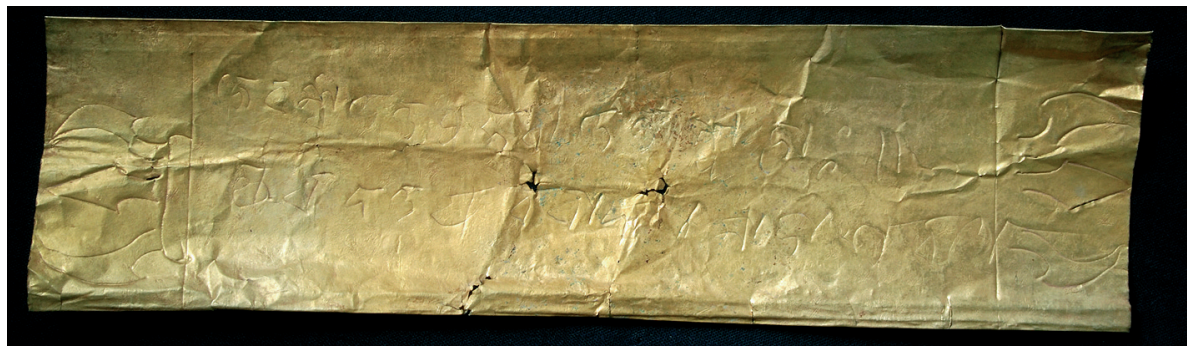

8. A ye dharmā inscription from Muara Jambi. (Photo Pierre-Yves Manguin, 2010)

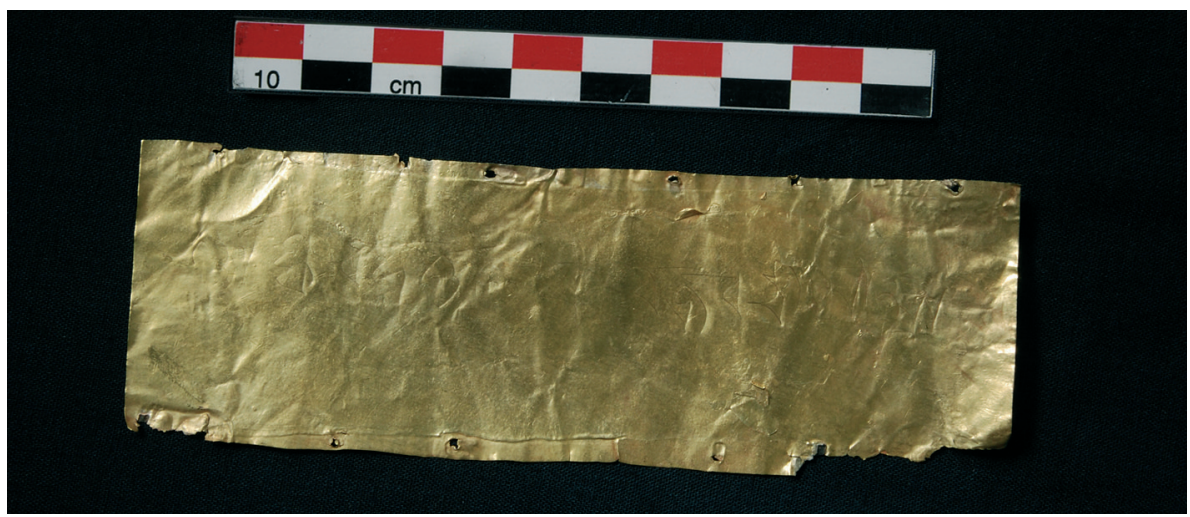

9. Inscribed gold leaf from Muara Jambi. (Photo Pierre-Yves Manguin, 2010)

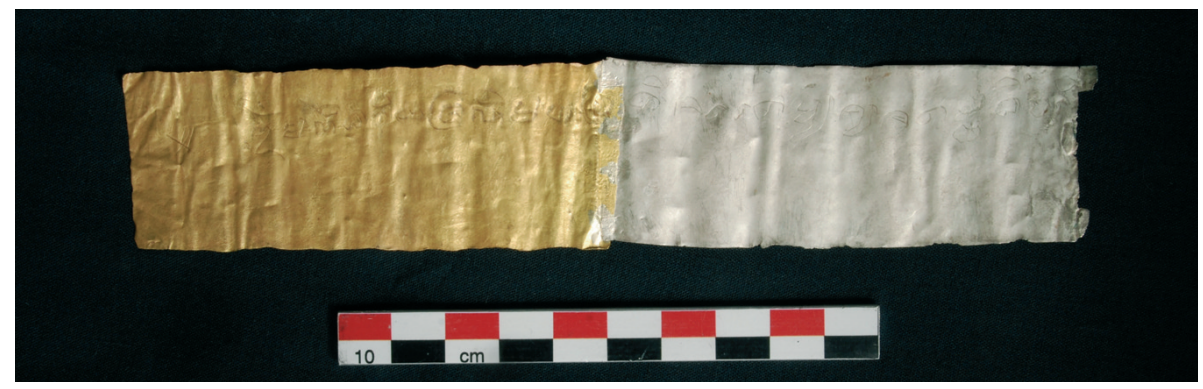

10. Inscribed gold and silver leaf from Muara Jambi. (Photo Pierre-Yves Manguin, 2010) 
phat phat svāhāa!' that is found in the ritual manual Mahāpratisarāvidyāvidhi (see Hidas 2010: 476 and 481 for text and translation), with a name filled in in the place of dharakasya, but the differences between the mantra in this text and what we see on the Muara Jambi plaque seem insurmountable.

\section{*11. Inscribed bricks at Muara Jambi}

Like Bumi Ayu in South Sumatra (see item 6 above), this site has yielded a great number of bricks inscribed with symbols, a small number of which are clearly alphabetic, others appear to be so at first sight but are in fact more likely to be non-alphabetic symbols (of various types). See the remarks of Jacq-Hergoualc'h (1992: 233f.), who shows a few similar inscribed bricks excavated at the site of Pengkalan Bujang in Malaysia, and cites in French translation from Sri Soejatmi Satari (1985: 74), whom we may here cite in the original English:

\footnotetext{
"During the process of dismantling prior to the restoration of the temples carried out by the Directorate for the Protection and Development of Historical and Archaeological Heritage, a huge amount of bricks incised with a variety of symbols and lines have been found, especially at Candi Gumpung. About 8 kinds of motifs have been observed. Some of the bricks are incised with a kind of formula, while others were impressed with prints of animal feet including those of a cock, a dog, a goat, and a cow. Similar prints were also found on the bricks of Trowulan. In Muara Jambi such prints were only found on the bricks of Candi Gumpung."
}

There is also an article dedicated to these brick inscriptions by Machi Suhadi (1985), which is not mentioned in PPS. 44 Machi Suhadi has dated the inscriptions from the $10^{\text {th }}-12^{\text {th }}$ centuries, on palaeographic grounds, which seems approximately acceptable. 45 I cannot agree with him, however, that both character and language are Old Javanese. Not wishing to enter again into the problem of nomenclature for script (already alluded to above, p. 17), I may limit myself to observing that there is insufficient basis to claim that the language here is Old Javanese, which would anyhow be rather unlikely. Machi Suhadi has published in his article a "list of the short inscriptions in Muara Jambi", which includes indication of the respective shrines where they were found, their numbers attributed by the site museum, handdrawings, and a reading as script of each sign. He does not mention the

44. Machi Suhadi's article also includes a short notice of a gong inscribed with Chinese characters, which figures in the catalogue PPS as SBT 02. Here too, Suhadi's article has escaped the compiler's attention, as has the in-depth study on this gong by Salmon (2003). See also Salmon (2008).

45. Although Boechari (1985: 238) has further specified: "the script on the bricks indicates at least two different types. The one is contemporaneous with the script of the gold plates [PPS, SBT 03, which Boechari implicitly dates to the 9th-10th centuries], while the other shows characteristics of the East-Javanese script dating from the $11^{\text {th }}-12^{\text {th }}$ centuries A.D., viz. squarish and upright". 
possibility that some of the signs have no alphabetical value. As figure $11, \mathrm{I}$ show a number of these bricks that are stored in the site museum. Only a few of them, such as fig. 11a (ma), 11c (bhuma or guma), 11d (si), 11i $\left(k^{*}\right), 11 \mathrm{j}$ ( $k a)$ can be said to bear signs that are writing. These appear to be Machi Suhadi's numbers 3, 21 (he reads gama), 1, 11 (?), and 22 (?).46 But the significance of these stray akșaras is difficult to guess, and some of the signs which resemble akșaras on other bricks (11b, 11e-h and 11k-m) still seem too different (and too consistently so) from the normal shapes of any proper akșaras to be classified as signs of writing. They may instead have been artisans' marks, or have had some other symbolic value. None of what Machi Suhadi has written about the meaning of these signs is convincing: in some cases he proposes that they are (abbreviations of) Old Javanese words, but the only full word he believes to have recognized (gama) is likely to have been misread; in others that they are Buddhist magical syllables, but the syllables in question do not show any of the typical features of such $b \bar{\imath} j a s$ (e.g. the presence of complex consonant clusters at the beginning or the presence of the signs $m$ or $h$ at the end).

\section{DHARMASRAYA IN SUMATRA BARAT}

\section{*12. An inscribed tablet found at Pulau Sawah}

This is a fragment of a small tablet of stone inscribed on three elongated faces with a Sanskrit stanza in the anuștubh (śloka) meter that is quoted from an important Mahāyāna Buddhist text, the Suvarṇabhāsottamasūtra, where it is stanza 3.71.47 The object was shown during the presentation of Budi Istiawan at the $13^{\text {th }}$ Conference of the European Association of Southeast Asian Archaeologists at Berlin, in September 2010.48 It was discovered in 2008 at the site of Pulau Sawah lying near the Batang Hari river, far upriver from Muara Jambi. 49 Precise information on the dimensions is not yet

\footnotetext{
46. Since no numbers appeared to be associated with the bricks in the site museum when we visited, I am unable to restore with full confidence all the correspondences between Machi Suhadi's own numbers, the museum numbers he cites, and the bricks we have photographed.

47. See the editions of Nobel (1937) and Skjaerv $\varnothing$ (2004). We see in the verb forms (bhaveya, deśeya, moceya, only one of them preserved on this artifact) a grammatical trace of the particular form of Sanskrit that is found in parts of Buddhist literature, called Buddhist Hybrid Sanskrit (in classical Sanskrit, the forms should be bhavey am etc.).

48. I am grateful to Drs. Budi Istiawan of the BPPP at Batu Sangkar, West Sumatra, and his director Drs. Fitra Arda (M. Hum), for their permission to publish the photos shown here.

49. Administrative divisions according to information received from Budi Istiawan: jorong Siguntur Bawah, nagari Siguntur, kecamatan Sitiung, kabupaten Dharmasraya. Not much has been published thus far about the site, which is gradually being excavated by BPPP Batu Sangkar. For impressions based on campaigns prior to the one which yielded the artifact to be discussed here, see Surya Helmi and others 1997, and Budi Istiawan 2006.
} 


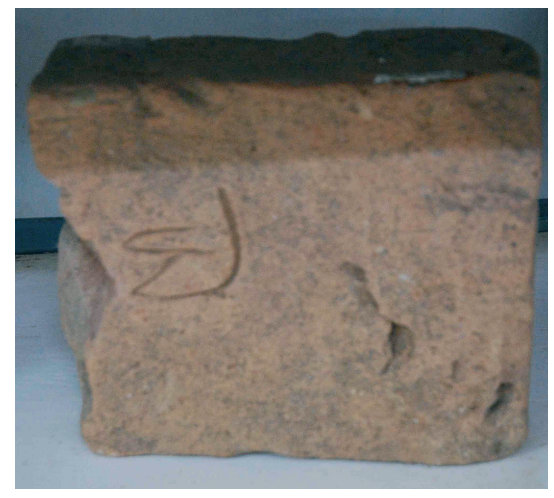

$\mathbf{a}$

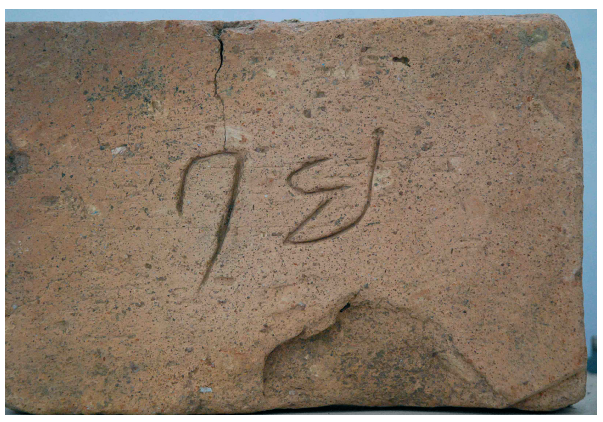

c

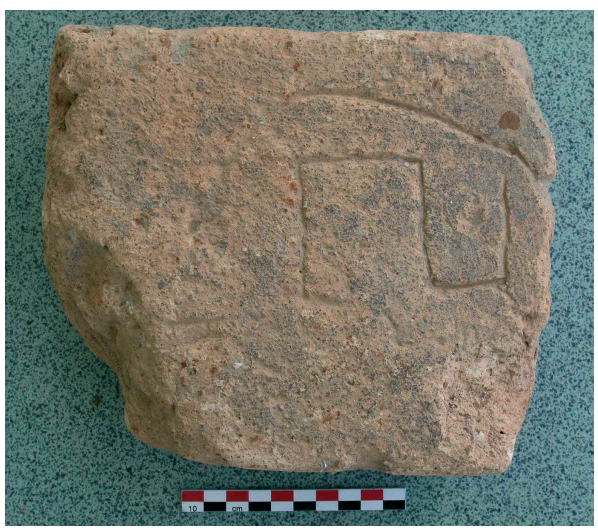

e

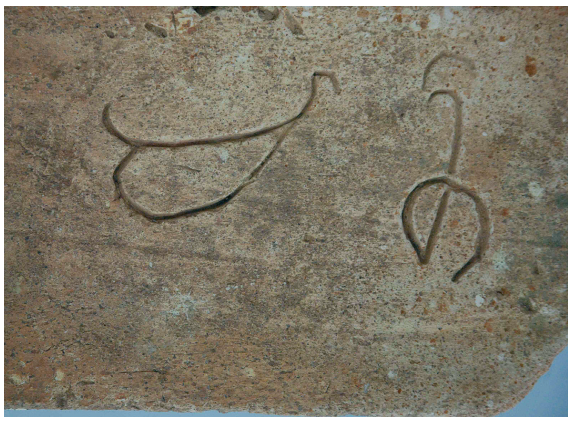

b

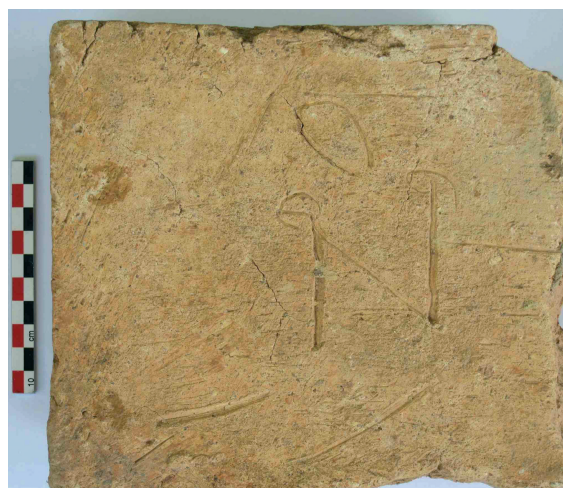

d

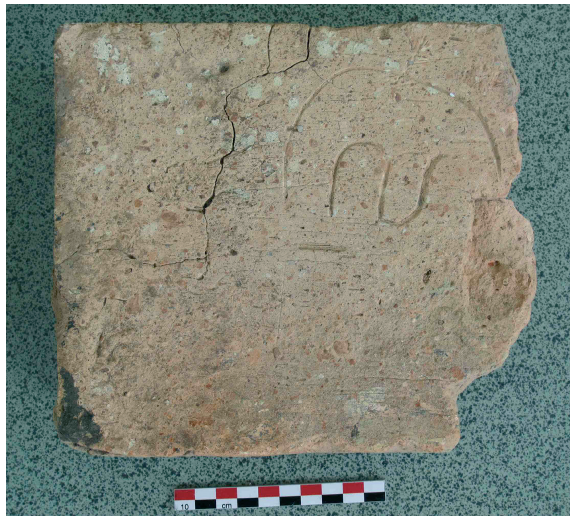

f

Archipel 81, Paris, 2011 


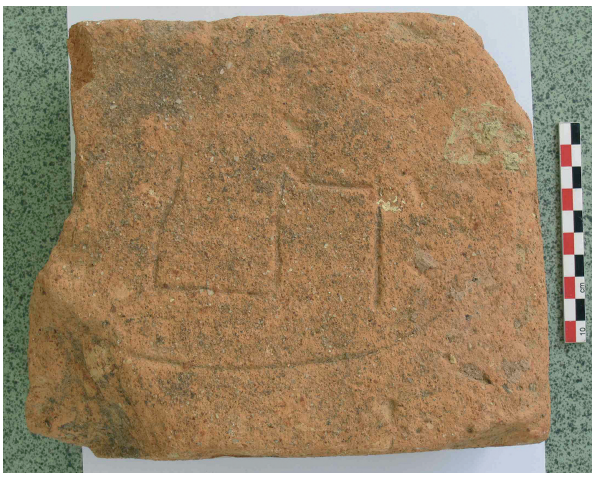

g

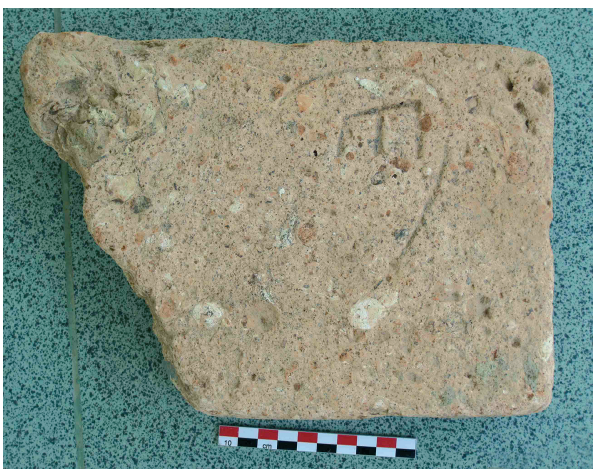

i

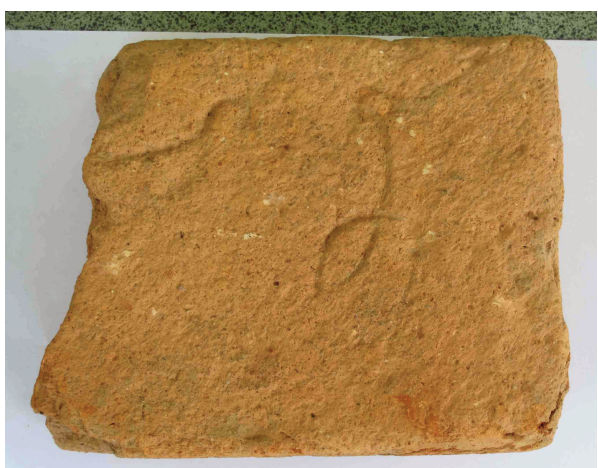

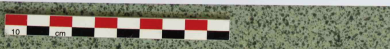

k

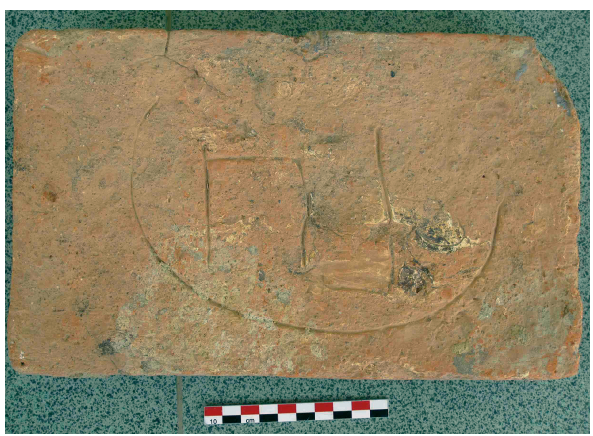

h

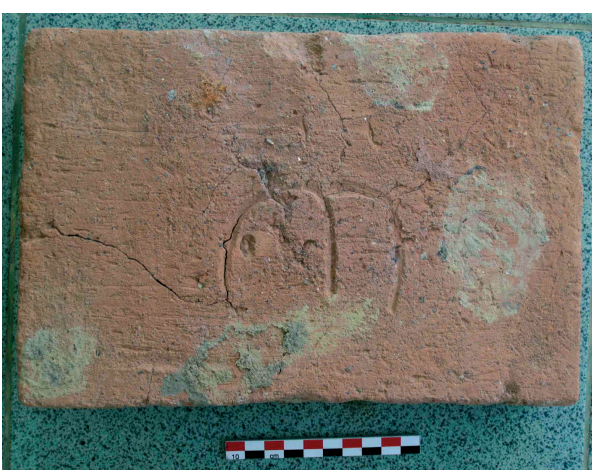

j

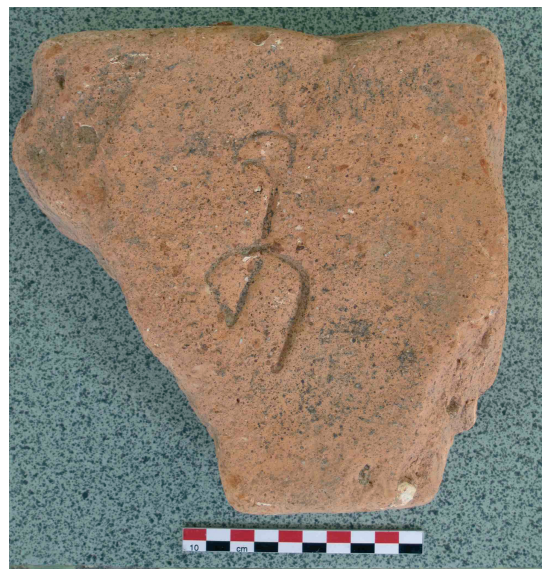

I

Archipel 81, Paris, 2011 


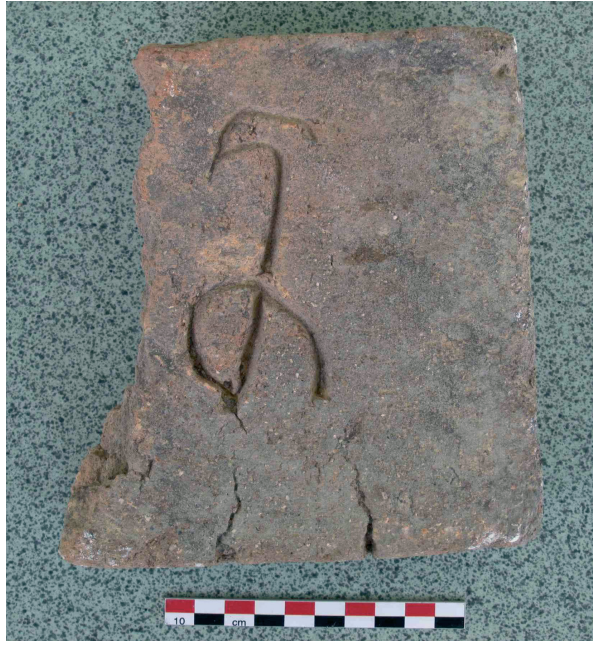

m

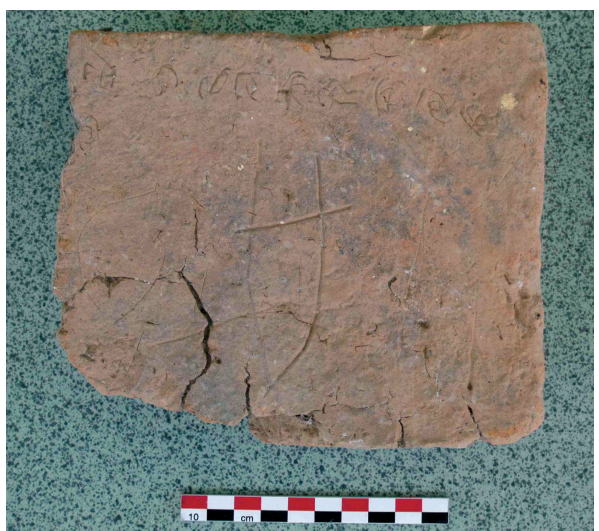

о

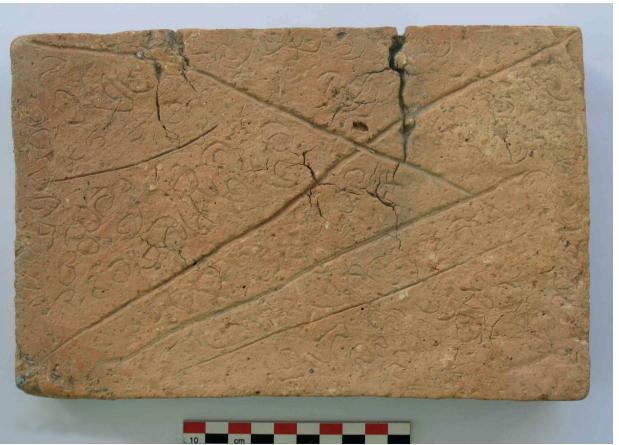

$\mathbf{n}$

11a-o. Inscribed bricks from Muara Jambi.

(Photos a-c by Véronique Degroot, 2008 and d-o by Arlo Griffiths, 2010) 
available, but it may be estimated on the basis of the match-stick used as scale in the photos (fig. $12 \mathrm{a}-\mathrm{c}$ ). In the edition below, bold letters indicate those preserved on the fragment, the other letters being supplied from the editions of the Sūtra. Letters inside (...) are difficult to read but almost certainly present.

(A1) anena cāhạ̣ kuśale(na) ka(r)mma(A2)ṇā bhaveya buddho nare(A3)ṇa 50 lo(ke)

deśeya dha(B1)rmmaṃ jagato hitāya

(C1) moceya satvā(mạ) vahuduḥ(C2)khapiẹ̣itān• II

'And by this good deed may I soon become a Buddha in the world. May I teach the Dharma for the benefit of the world. May I release creatures tortured by many sufferings.'

The present object is inscribed in a form of script that resembles closely the script of Javanese inscriptions of the $9^{\text {th }}-10^{\text {th }} \mathrm{c}$. CE (the shape of the viräma/paten at the end is archaic). The object may have been imported from Java, but may also have been engraved locally, for (as observed above, p. 17) we do not know whether Sumatran writing at this time differed yet in any appreciable way from writing in Java. The palaeographic dating is supported by the archaeological context, which reportedly has yielded several sculptures that must be dated to the same period on stylistic grounds. 51 The text has been engraved with little attention. In the portion preserved on this fragment, one akșara has been forgotten entirely; one consonant sign $t$ has been engraved so carelessly that it cannot be distinguished from $k$.

This inscribed tablet belongs to the category that Peter Skilling has called "citation inscriptions" (1999: 171), comprising pithy statements from scriptural texts, epitomes of Buddhist doctrine intended for liturgical purposes. While citations in Pali seem to be somewhat more common, e.g. in Burma, examples of citation inscriptions in Sanskrit verse-form are extremely rare anywhere in South and Southeast Asia. The citation of a verse from the Mahāyāna Buddhist Bhadracaripraṇidhāna in a $10^{\text {th }}$ century inscription on a miniature stūpa from Nālandā in India has become well-known thanks to an article by Gregory Schopen, specialist of the history of Indian Buddhism and Buddhist epigraphy (1989). Less well-known but more comparable to our tablet in size and form are two tablets engraved with stanzas from the

50. narena: this is a mistake for nacirena, see the editions by Nobel and Skjaerv $\varnothing$.

51. No images of the statuary recovered from the site, some examples of which were shown by Budi Istiawan at Berlin, are available to me. All archaeologists present during his presentation agreed that they seem point in stylistic terms towards a date in the range 800-1000 CE. The statuary was shown too briefly, however, to be able to exclude the possibility that all or some pieces must date from earlier or later periods. 

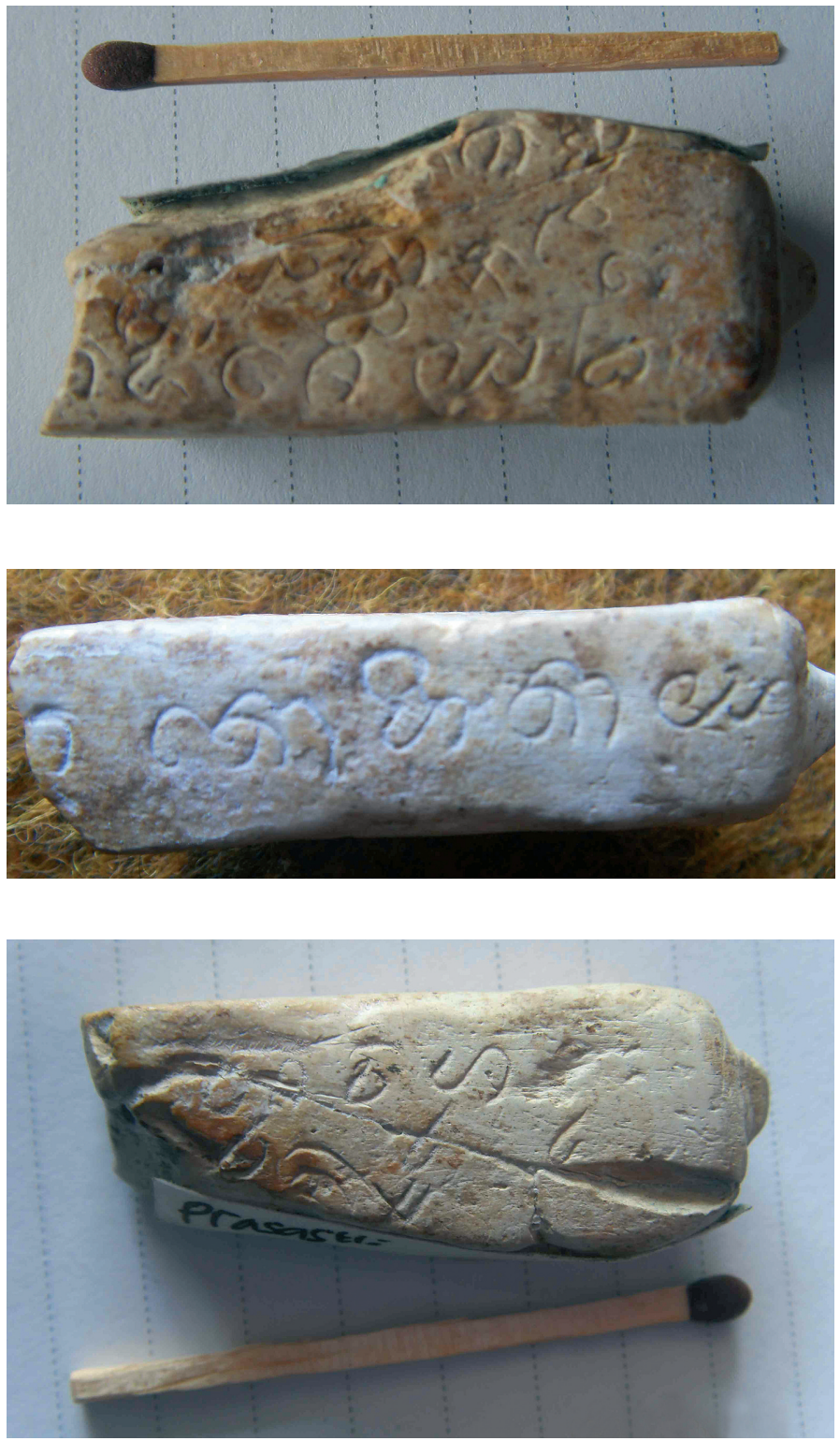

12a-c. Inscribed tablet from Pulau Sawah. (Photos Budi Istiawan, 2008) 
Sägaramatipariprcchāsūtra, 52 which have been found at sites in peninsular Malaysia (in South Kedah), and are both datable probably to the second half of the first millennium CE. 53 None of these objects necessarily constitute evidence of the circulation of the cited texts as such. So while the specialists of Buddhist studies whom I have consulted suggest that this may be the first known epigraphical excerpt from the Suvarnabhāsottamasūtra, anywhere in Buddhist South and Southeast Asia, we should be careful not immediately to draw the conclusion that we now have evidence for this text having been studied in ancient Indonesia, although of course this remains a possibility. 54 In the absence of detailed information about the precise shape of the object (especially the roundish protuberance it seems to show on one end) and its archaeological context, it is impossible to propose any serious hypothesis concerning its liturgical use. One possibility that cannot yet be excluded is that this tablet was to be inserted in some kind of contraption and used as a 'prayer wheel'. What is certain, however, is that we have with this tablet the first written evidence of Buddhist cult practices in the upstream area of the Batang Hari basin, several centuries before this area became part of Ādityavarman's kingdom.

\section{CONCLUSION}

In focusing on the provinces Sumatra Selatan and Jambi, I have been able to add here 9 inscriptions or groups of inscribed objects not included in Bambang Budi Utomo's catalogue, which counts 78 items in total. In other words, it has been possible to raise the count to 87 (an increase exceeding $10 \%$ ) for the whole island by attempting to complete the data from two of

52. See the identification of the text furnished by Lin Li-Kouang cited in Quaritch Wales 1940: 8-10.

53. Cf. Jacq-Hergoualc'h 1992: 228-229 (with photos after Quaritch Wales 1940) and 2002: 207-210 (without photos) for discussion of a three-faced tablet which is attributed to the "beginning of the $5^{\text {th }}$ or first half of the $7^{\text {th }}$ century", and bears three Sanskrit stanzas. Another similarly shaped tablet, which seems a few centuries later, has recently been brought to light at excavations in South Kedah under the responsibility of Mokhtar Saidin. It seems to bear only the last two of the three stanzas seen on the other tablet. As far as I know, it is not yet published. On the epigraphy of South Kedah, see also Allen 1986-87.

54. It may be noted that Schopen is not so reticent with regard to the possible significance of the citation from the Bhadracaripranidhāna in the Nālandā inscription as evidence for the circulation of that text. See Schopen 1989 (cited from the 2005 reprint: 300): "The primary importance of our inscription, however, must lie in the fact that it contains the only verse of the Bhadracaripranidhana known to occur in an Indian epigraph, and its occurrence establishes the fact that the Bhadracari was known and used in the tenth century at Nālandā." But see also the more careful formulation in his n. 10 that the verse "appears to occur nowhere else" so that "knowledge of the verse might in this case, therefore, be taken to imply knowledge of the text as a whole." 
the eight provinces on the island and by including one specific find from Sumatra Barat. This suggests that epigraphists may reasonably expect to come up with quite a bit of new data if a dedicated field campaign is undertaken covering the whole island of Sumatra. I have also provided first or significantly improved readings and some important metadata about 3 items included by Bambang Budi Utomo, illustrating how much progress can and must still be made by epigraphists before the data contained even in those inscriptions which are included in the published catalogue can really start to be harvested. Sumatran epigraphy is a small but exciting field in which it seems that a lot still lies to be discovered. While political or economic history may not stand to gain much from further discoveries, it is especially our perspective on the history of Buddhist institutions and practices in Sumatra, which stands to become significantly enriched as new discoveries become known to scholarship. Furthermore, it is quite likely that fortunate new discoveries will help further enrich our knowledge of the Old Malay language.

\section{REFERENCES}

Adelaar, K. Alexander, 1992, Proto-Malayic: the reconstruction of its phonology and parts of lexicon andmorphology. Canberrra: ANU/Pacific Linguistics.

Allen, S. Jane, 1986-87, “An inscribed tablet from Kedah, Malaysia: comparisons with earlier finds", Asian Perspectives 27: 35-57.

Boechari, 1985, "Ritual deposits of Candi Gumpung (Muara Jambi)", in: Country Report of Indonesia for SPAFA, Final Report, Consultative Workshop on Archaeological and Environmental Studies on Srivijaya $(I-W 2 b)$, Bangkok: SPAFA, Appendix $7 \mathrm{~d}$ : 229-243.

-. 1986, "New Investigations on the Kedukan Bukit Inscription", in: Untuk bapak guru. Persembahan para murid untuk memperingati usia genap 80 tahun Prof. Dr. A.J. Bernet Kempers, Jakarta: Pusat Penelitian Arkeologi Nasional/ Departemen Pendidikan dan Kebudayaan: 33-56. [This volume was reprinted in 2008.]

Bosch, F.D.K., 1927, "Gouden vingerringen uit het hindoe-javaansche tijdperk”, Djåwå 7: 305-320.

Boucher, Daniel, 1991, "The Pratītyasamutpādagāthā and Its Role in the Medieval Cult of Relics", Journal of the International Association of Buddhist Studies 14: 1-27.

Brinkgreve, Francine \& Retno Sulistianingsih (eds.), 2009, Sumatra: Crossroads of Cultures. Leiden: KITLV Press.

Casparis, J.G. de, 1956, Selected inscriptions from the $7^{\text {th }}$ to the $9^{\text {th }}$ century A.D. [Prasasti Indonesia II.] Bandung: Masa Baru.

Chhabra, B. Ch., 1965, Expansion of Indo-Aryan Culture During Pallava Rule (as evidenced by inscriptions). Delhi: Munsi Ram Manohar Lal.

Chutiwongs, Nandana, 1998, "Some ancient Indonesian gold and silver images and other objects in the National Museum of Ethnology, Leiden", in: Marijke J. Klokke \& Thomas de Bruijn (eds.), Southeast Asia Archaeology 1996, Hull: Centre for SouthEast Asian Studies: 218-230. 
Cruijsen, Thomas, Arlo Griffiths \& Marijke Klokke, forthcoming "The Cult of the Buddhist Dhāraṇī Deity Mahāpratisarā along the Maritime Silk Route: new epigraphic and iconographic evidence from the Indonesian Archipelago".

Damais, Louis-Charles, 1955a, «Les écritures d'origine indienne en Indonésie et dans le Sud-Est Asiatique continental», Bulletin de la société des études indochinoises 30: 365-382. [Translated in Damais 1995: 3-22.]

- 1955 b, «Études d'épigraphie indonésienne. IV. Discussion de la date des inscriptions », BEFEO 47: 7-290.

—. 1968, «Bibliographie indonésienne: XI. Les publications épigraphiques du service archéologique de l'Indonésie», BEFEO 54: 295-521.

- 1970, Répertoire onomastique de l'épig raphie javanaise (jusqu'à pu Sindok Śrī İsānawik rama Dharmottungadewa), Paris: École française d'Extrême-Orient.

-. 1995, Epigrafi dan Sejarah Nusantara. Pilihan Karangan Louis-Charles Damais. Jakarta: EFEO.

Helmi Surya, Marsis Sutopo, Teguh Hidayat, Budi Istiawan, 1997, "Kepurbakalaan DAS Batang Hari, Sumatera Barat: suatu paparan singkat", in: Cinandi: Persembahan alumni Jurusan Arkeologi Universitas Gadjah Mada kepada Prof. Dr. H.R. Soekmono, diterbitkan oleh: Panitia Lustrum VII, Jurusan Arkeologi Fakultas Sastra, Universitas Gadjah Mada: 51-60.

Hidas, Gergely, 2007, "Remarks on the Use of the Dhäranīs and Mantras of the Mahāpratisarā-Mahāvidyārājiñ̄”, in: Cs. Dezső (ed.), Indian Languages and Texts through the Ages: Essays in Honour of Prof. Csaba Töttössy, Delhi: Manohar: 185207.

—. 2010, "Mahāpratisarāvidyāvidhi. The spell-manual of the great amulet", Acta Orientalia Academiae Scientiarum Hung. 63: 473-484.

Istiawan, Budi, 2006, "Jejak sejarah dan kepurbakalaan Dharmasraya", in: Menguak Tabir Dharmasraya, Batu Sangkar: Balai Pelestarian Peninggalan Purbakala: 1-32.

Jacq-Hergoualc'h, Michel, 1992, La civilisation des ports-entrepôts du Sud Kedah (Malaysia) Ve-XIVe siècle. Paris: 1'Harmattan.

-. 2002, The Malay Peninsula. Crossroads of the Maritime Silk Road(100 BC-1300 $A D)$. Leiden: Brill.

Lamb, Alastair, 1964, "Mahayana Buddhist Votive Tablets in Perlis", JMBRAS 37: 4759.

Lunsingh Scheurleer, Pauline, forthcoming "Images of Local Javanese Deities", in: Véronique Degroot, Marijke J. Klokke \& Pauline Lunsingh Scheurleer (eds.), Materializing Southeast Asia's Past: Selected Papers from the $12^{\text {th }}$ International Conference of the European Association of Southeast Asian Archeologists.

Manguin, Pierre-Yves, 1987, Report on the Kampung Sambirejo boat remains and on a short visit to Srivijayan sites, Palembang, 21 -23 September 1987, Jakarta: EFEO/Pusat Penelitian Arkeologi Nasional, 1987, unpublished report, 32 p., map, 24 ills.

Nihom, Max, 1998, "The mandala of Candi Gumpung (Sumatra) and the Indo-Tibetan Vajraśekharatantra", Indo-Iranian Journal 41: 245-254.

Nobel, Johannes, 1937, Suvarnabhāsottamasūtra. Das Goldglanz-Sūtra: ein Sanskrittext des Mahāyāna-Buddhismus nach den Handschriften und mit Hilfe der Tibetischen und Chinesischen Übertragungen herausgegeben. Leipzig: Otto Harrassowitz.

Perquin, P.J., 1928, “Oudheidkundig Onderzoek te Palembang”, OV 1928: 123-128.

Purwanti, Retno, 1994, "Bata bertulis kaitannya dengan bangunan Candi 1 Bumiayu", Berkala Arkeologi (Yogyakarta) 14 [Edisi khusus: Evaluasi Sejarah dan Interpretasi baru Sejarah Indonesia Kuno (Dalam Rangka Purna Bhakti Drs. M.M. Soekarto Karto Atmojo) Yogyakarta 23-24 Maret 1994]: 207-215. 
Quaritch Wales, H.G., 1940, “Archaeological Researches”, JMBRAS 18 (1): 1-85.

Salmon, Claudine, 2003, "A tentative Interpretation of the Chinese Inscription (1231) Engraved on a Bronze Gong Recovered in Muara Jambi (Central Sumatra)", Archipel 66: 91-112.

-. 2008, "The Chinese Origin of the Muara Jambi Gong as Evidenced by a New Archaeological Find", Archipel 76: 7-14.

Satari, Sri Soejatmi, 1985, "Research activities in Indonesia, Sumatra", in: Country Report of Indonesia for SPAFA, Final Report, Consultative Workshop on Archaeological and Environmental Studies on Srivijaya $(I-W 2 b)$, Bangkok: SPAFA, Appendix 4b: 73-79.

Schopen, Gregory, 1989, "A Verse from the Bhadracaripranidhāna in a Tenth-Century Inscription Found at Nālandā", Journal of the International Association of Buddhist Studies 12(1): 149-157. [Reprinted with stylistic changes in Schopen 2005: 299305.]

-. 2005, Figments and fragment of Mahāyāna Buddhism in India. More collected papers. Honolulu: University of Hawai 'i Press.

Skilling, Peter, 1999, "A Buddhist inscription from Go Xoai, southern Vietnam and notes towards a classification of ye dharmā inscriptions", in: 80 pi śāstrācāry dr. prahsert na nagara: ruam pada khvam vijākāra dan charük lae ekasāraporānna [80 Years: A collection of articles on epigraphy and ancient documents published on the occasion of the celebration of the $80^{\text {th }}$ birthday of Prof. Dr. Prasert Na Nagara, Bangkok 21 March 2542] (Bangkok 1999): 171-187.

-. 2003-04, "Traces of the Dharma. Preliminary reports on some ye dhammā and ye dharmā inscriptions from Mainland South-East Asia", BEFEO 90-91: 273-287.

—. 2005, “'Buddhist sealings': Reflections on Terminology, Motivation, Donors' status, School-Affiliation, and Print-Technology", in: C. Jarrige \& V. Lefèv re (eds.), South Asian Archaeology 2001 (Proceedings of the Sixteenth International Conference of the European Association of South Asian Archaeologists, held in Collège de France, Paris, 2-6 July 2001), Paris, Vol. II: 677-685.

-. 2008, "Buddhist sealings and the ye dharmā stanza", in: Gautam Sengupta \& Sharmi Chakravorty (eds.), Archaeology of Early Historic South Asia, Delhi: Pragati Publications: 503-525.

Skjaerv $\varnothing$, Prods Oktor, 2004, The Most Excellent Shine of Gold, King of Kings of Sutras . The Khotanese Suvarnabhāsottamasutra. Volume I: The Khotanese Text With English Translation and the Complete Sanskrit Text. Harvard University: Department of Near Eastern Languages and Civilizations.

Stevens, Alan M. \& A. Ed. Schmidgall-Tellings, 2004, A Comprehensive IndonesianEnglish Dictionary. Athens, OH: Ohio University Press.

Strauch, Ingo, 2009, "Two Stamps with the Bodhigarbhālaṃkāralakṣa Dhāraṇi from Afghanistan and Some Further Remarks on the Classification of Objects with the ye dharmā Formula", in: Gerd J.R. Mevissen \& Arundhati Banerji (eds.) Prajñädhara, Essays on Asian Art, History, Epigraphy and Culture in Honour of Gouriswar Bhattacharya, New Delhi : Kaveri Books: 37-56.

Stutterheim, W.F., 1924, “Oudjavaansche plastiek in Europese musea”, BKI 80: 287-301.

Suhadi, Machi, 1976, "Inskripsi stempel dari Palembang", Buletin Yaperna No. 15, Thn. III (Juli 1976): 49-61.

-. 1985, "Inscriptions from Muara Jambi", in: Country Report of Indonesiafor SPAFA, Final Report, Consultative Work shop on Archaeological and Environmental Studies on Srivijaya (I-W2b), Bangkok: SPAFA, Appendix 7f: 257-262.

-. 1989, "Mantra Buddha dari Negara ASEAN", in: Proceedings Pertemuan Ilmiah Arkeologi V (Yogyakarta, 4-7 Juli 1989), part I: Studi Regional/Regional Studies, Ikatan Ahli Arkeologi Indonesia: 103-132. 
Sukarto K. Atmodjo, M.M., 1992, "Kontinuitas kerajaan Malayu Kuno dan Sriwijaya serta temuan prasasti Boom Baru di Palembang", in: Seminar Sejarah Malay u Kuno, Jambi, 7-8 Desember 1992, Pemerintah Daerah Tingkat I Jambi bekerjasama dengan Kantor Wilayah Departemen Pendidikan dan Kebudayaan Jambi: 271-296.

—. 1993a, "Prasasti Boom Baru dan kaitannya dengan kerajaan Sriwijaya", in: Sriwijaya dalam perspektif arkeologi dan sejarah, Pemerintah Daerah Tingkat I Sumatera Selatan [Palembang]: A2-1 through A2-8.

-. 1993b, "Om Myam", in: Sriwijay a dalam perspektif arkeologi dan sejarah, Pemerintah Daerah Tingkat I Sumatera Selatan [Palembang]: C6-3 through C6-5.

-. 1994, "Beberapa temuan prasasti baru di Indonesia", Berkala Arkeologi (Yogyakarta) 14 [Edisi khusus: Evaluasi Sejarah dan Interpretasi baru Sejarah Indonesia Kuno (Dalam Rangka Purna Bhakti Drs. M.M. Soekarto Karto Atmojo) Yogyakarta 23-24 Maret 1994]: 1-5.

Tokyo National Museum, 1997, Treasures of ancient Indonesian kingdoms. Tokyo: Tokyo National Museum.

Trigangga, 2009, "History of Indic writing and scripts in Sumatra", in: F. Brinkgreve \& Retno Sulistianingsih (eds.), Sumatra: Crossroads of Cultures: 85-95.

Tsukamoto, Keisho, 1996-1998, Indo Bukkyo Himei no Kenkyu, A Comprehensive Study of the Indian Buddhist Inscriptions, 2 parts, Kyoto: Heirakuji-Shoten .

Weatherbee, Donald E., 2000, "The Hyang Haji of the Gandasuli II Inscription, circa 832 AD", in: Lokesh Chandra (ed.), Society and Culture of Southeast Asia: Continuity and Changes, Delhi: International Academy of Indian Culture and Aditya Prakashan: 345353. 